\title{
CORRELATION BETWEEN THE MANTLE AND HETEROCHRONOUS CRUSTAL MATERIALS IN THE COMPOSITION OF TRANSBAIKALIA A-TYPE GRANITOIDES: PETROLOGICAL AND GEODYNAMICAL IMPLICATIONS
}

\author{
A. A. Tsygankov ${ }^{1,2}$, V. B. Khubanov ${ }^{1,2}$, G. N. Burmakina1, \\ A. L. Elbaev ${ }^{1}$, V. V. Burdukovsky ${ }^{1}$ \\ ${ }^{1}$ Geological Institute, Siberian Branch of RAS, Ulan-Ude, Russia \\ ${ }^{2}$ Buryat State University, Ulan-Ude, Russia
}

\begin{abstract}
Late Paleozoic and Early Mesozoic alkaline A-type granitoids (anhydrous, alkaline, moderately aluminous, ferruginous) are widely distributed in the structures of the Central Asian Fold Belt. In Northern Mongolia and Transbaikalia, there are hundreds of massifs that formed from the end of the Permian to the Middle Jurassic inclusive. These massifs are composed of alkaline granites, alkaline and alkali-feldspar syenites, and located within crustal blocks (terranes) of different ages and origins. New geochemical data obtained for the Kruchininsky, Sherbakhtinsky, Shabartay and Khamney massifs, as well as earlier published materials (Bryansk and Kharitonovo plutons), demonstrate that despite the general petrogeochemical similarity of the main rock types composing these plutons, their isotopic composition (Nd) differs significantly. Our studies suggest that the isotopic composition of Transbaikalia A-type granitoids is caused, on the one hand, by the crust permeability for mantle magmas and, on the other hand, by the material heterogeneity of the crustal magma sources themselves, varying from the Early Precambrian crystalline blocks to 'young' island-arc terranes.
\end{abstract}

Key words: A-type granitoids; crustal and mantle magma sources; isotopic composition; intraplate magmatism; geodynamics; Transbaikalia

For citation: Tsygankov A.A., Khubanov V.B., Burmakina G.N., Elbaev A.L., Burdukovsky V.V., 2019. Correlation between the mantle and heterochronous crustal materials in the composition of Transbaikalia A-type granitoides: petrological and geodynamical implications. Geodynamics \& Tectonophysics 10 (3), 779-799. doi:10.5800/GT-2019-10-3-0441. 


\title{
СООТНОШЕНИЕ МАНТИЙНОГО И РАЗНОВОЗРАСТНОГО КОРОВОГО ВЕЩЕСТВА В СОСТАВЕ ГРАНИТОИДОВ ЗАБАЙКАЛЬЯ А-ТИПА: ПЕТРОЛОГИЧЕСКИЕ И ГЕОДИНАМИЧЕСКИЕ СЛЕДСТВИЯ
}

\author{
А. А. Цыганков ${ }^{1,2}$, В. Б. Хубанов ${ }^{1,2}$, Г. Н. Бурмакина', \\ А. Л. Елбаев ${ }^{1}$, В. В. Бурдуковский 1 \\ ${ }^{1}$ Геологический институт СО РАН, Улан-Удэ, Россия \\ ${ }^{2}$ Бурятский государственный университет, Улан-Удэ, Россия
}

\begin{abstract}
Аннотация: Позднепалеозойские и раннемезозойские щелочные гранитоиды А-типа (сухие, щелочные, умеренно-глиноземистые, железистые) широко распространены в структурах Центрально-Азиатского складчатого пояса. В Северной Монголии и Забайкалье известны сотни массивов, формировавшихся с конца пермского периода до средней юры включительно. Эти массивы сложены щелочными гранитами, щелочными и щелочно-полевошпатовыми сиенитами и расположены в пределах блоков коры (террейнов) разного возраста и происхождения. Новые геохимические данные, полученные по Кручининскому, Шербахтинскому, Шабартайскому и Хамнейскому массивам, в совокупности с опубликованными ранее (Брянский, Харитоновский плутоны), показывают, что при общем петрогеохимическом сходстве основных разновидностей пород, слагающих эти плутоны, их изотопный состав $(\mathrm{Nd})$ существенно различается. Проведенные исследования дают основание полагать, что изотопный состав гранитоидов Забайкалья А-типа обусловлен, с одной стороны, проницаемостью коры для мантийных магм, а с другой - вещественной гетерогенностью собственно коровых источников магм, варьирующихся от раннедокембрийских кристаллических блоков до «молодых» террейнов островодужного типа.
\end{abstract}

Ключевые слова: гранитоиды А-типа; коровые и мантийные источники магм; изотопный состав; внутриплитный магматизм; геодинамика; Забайкалье

\section{1. ВВЕДЕНИЕ}

Граниты А-типа, первоначально определенные как «анорогенные», т.е. образующиеся значительно позже финальных тектономагматических событий [White, 1979; Whalen et al., 1987; Collins et al., 1982], как выяснилось, формируются в разных геодинамических обстановках [Eby, 1992; Sylvester, 1989; Barbarin, 1999], причем одновременно с гранитоидами других типов [Wu et al., 2002; Kruk et al., 2011; Litvinovsky et al., 2011; Tsygankov, 2014; Tsygankov et al., 2010]. Тем не менее их минералого-геохимические характеристики (сухие, щелочные, умеренноглиноземистые, железистые) вполне определенны, что позволяет достаточно надежно диагностировать данный тип гранитов, несмотря на всю дискуссионность этого вопроса (см. материалы VI Хаттоновского симпозиума «Происхождение гранитов и ассоциированных пород», 2007, а также обзор в [Grebennikov, 2014]). Кроме того, выяснилось, что рассматриваемые граниты всегда содержат значительную долю, до 100 \%, ювенильного (мантийного) компонента [Frost C.D., Frost B.R., 2011]. При этом механизм инкорпорирования этого мантийного вещества может быть разным - от дифференциа- ции щелочно-базальтовых магм до смешения коровых и мантийных расплавов и плавления метабазитов [Loiselle, Wones, 1979; Eby, 1990; Turner et al., 1992; Collins et al., 1982; Whalen et al., 1987; Creaser et al., 1991; Patiño Douce, 1997].

Таким образом, можно констатировать, что одновременно с более распространенными разновидностями гранитоидов (в широком смысле этого термина) в разных геодинамических обстановках образуется весьма специфичный тип пород, называемый граниты А-типа. Сегодня уже очевидно, что A-граниты образуются разными путями, однако причины и условия, при которых разные петрогенетические процессы приводят к сходному результату (с учетом всего разнообразия А-гранитов), вопрос открытый и широко обсуждаемый.

Представляется, что прогресс в понимании природы А-гранитов, а именно тех разновидностей, которые формируются в пределах континентальных сегментов литосферы, может быть достигнут путем детального анализа главных петрогенетических факторов в максимально «чистом» виде. Иначе говоря, необходимо изучить влияние таких факторов, как зрелость и реологическое состояние коры, мантийный вклад (геохимический тип мантийного ве- 
щества, его доля в составе гранитоидов, механизм инкорпорирования), роль процессов фракционной кристаллизации и т.д., каждого по отдельности, при максимально равных прочих условиях.

В настоящем сообщении приводятся новые результаты геохимического и изотопно-геохронологического изучения нескольких щелочно-гранитоидных плутонов Забайкалья, сложенных однотипными породами, но сформировавшихся в разное время и, что особенно важно, в разной геодинамической обстановке, т.е. в сегментах континентальной коры разной «степени зрелости». В качестве геодинамической основы, характеризующей «степень зрелости коры», нами использована схема террейнов Саяно-Байкальской складчатой области [Bulgatov, Gordienko, 1999]. Для сравнения используются опубликованные данные по эталонным Брянскому [Litvinovsky et al., 2002] и Харитоновскому [Zanvilevich et al., 1995] плутонам, сложенным щелочно-полевошпатовыми сиенитами (AFS alkali-feldspar - щелочно-полевошпатовые) и щелочными гранитами (PA - peralkaline - пересыщенные щелочами).

\section{2. ГЕОЛОГИЧЕСКОЕ ПОЛОЖЕНИЕ}

Позднепалеозойские и раннемезозойские щелочные гранитоиды А-типа широко распространены в структурах Центрально-Азиатского складчатого пояса. Они протягиваются в виде гигантского пояса в северо-восточном направлении более чем на 6000 км, от Восточного Казахстана через СевероЗападный Китай, Северную Монголию и Забайкалье до Алданского щита [Jahn et al., 2009]. В пределах Монголо-Забайкальского сектора, протяженностью более 2000 км и шириной 150-250 км, известно около 350 массивов (рис. 1), сложенных щелочными гранитами, щелочными и щелочно-полевошпатовыми сиенитами А-типа [Zanvilevich et al., 1995], формировавшимися с ранней перми до средней юры включительно. Размеры плутонов, сложенных щелочными гранитоидами, варьируются от первых квадратных километров до сотен и даже тысяч квадратных километров. Небольшие тела, как правило, сложены одним типом пород, тогда как крупные плутоны, такие как Брянский (1600 км²) и Хоринский (2000 км²), образовались в результате нескольких последовательных внедрений щелочносиенитовых (нордмаркитовых) и щелочно-гранитных магм [Litvinovsky et al., 2002, 2011], причем во всех известных случаях сиениты предшествуют гранитам.

Пояс щелочных гранитов, сиенитов и ассоциирующих вулканогенных образований пересекает самые разные по возрасту и геодинамической при- роде структуры восточной части Центрально-Азиатского складчатого пояса (ЦАСП). В Забайкалье массивы А-гранитов располагаются в пределах разновозрастных (от палеопротерозоя до раннего палеозоя включительно) кратонных, метаморфических, островодужных и флишевых террейнов [Bulgatov, Gordienko, 1999], реконструируемых по разрозненным фрагментам, сохранившимся в виде провесов кровли среди обширных полей позднепалеозойских (325-280 млн лет) гранитоидов Ангаро-Витимского батолита (АВБ).

Кручининский щелочно-гранитоидный плутон расположен в западной части Алданского щита, примерно в 60 км к северо-востоку от г. Читы. Массив располагается на юго-восточном склоне хр. Черского, входящего в систему Яблонового хребта (Забайкальский край) в бассейне р. Кручина, в ее верхнем течении. В плане массив имеет неправильно каплевидную форму, вытянутую в северовосточном направлении (рис. 2). Площадь массива около 170 км². Массив залегает среди палеозойских биотитовых гранитов и лишь местами контактирует с биотитовыми и амфибол-биотитовыми гнейсами и кристаллическими сланцами застепинской толщи, предположительно протерозойского возраста. Кристаллические сланцы и гнейсы сохранились лишь в виде разновеликих останцев, площадью в десятки квадратных километров, среди палеозойских гранитоидов.

В строении Кручининского массива принимают участие две основных разновидности пород. Преобладают среднекрупнозернистые, местами порфировидные $(K f s)$ амфиболовые $( \pm B t)$ граниты, сложенные грубопертитовым K-Na полевым шпатом (Kfs), кварцем (Qtz), амфиболом (Amph) (магнезиальная роговая обманка, иногда катафорит) и небольшим количеством кислого плагиоклаза (Pl). Акцессорные минералы: магнетит, фтор-апатит (содержит до 5.5 мас. \% F), титанит, содержащий до 3-4 мас. \% оксидов LREE, магнетит, циркон, ортит. В подчиненном количестве развиты лейкократовые мелкозернистые порфировидные (Qtz) граниты, в которых единственным темноцветным минералом является железистый биотит (аннит), а количество плагиоклаза и пертитового K-Na полевого шпата примерно одинаково. К перечисленным выше акцессорным минералам амфиболовых гранитов добавляется манган-ильменит, содержащий до 12 мac. \% MnO. В дальнейшем для краткости и удобства преобладающую разновидность мы будем называть щелочными гранитами, а вторую - гранит-порфирами, или щелочными гранит-порфирами, поскольку по уровню общей щелочности они практически не различаются.

Шербахтинский сиенит-щелочно-гранитный массив (рис. 3) располагается в северо-восточной 


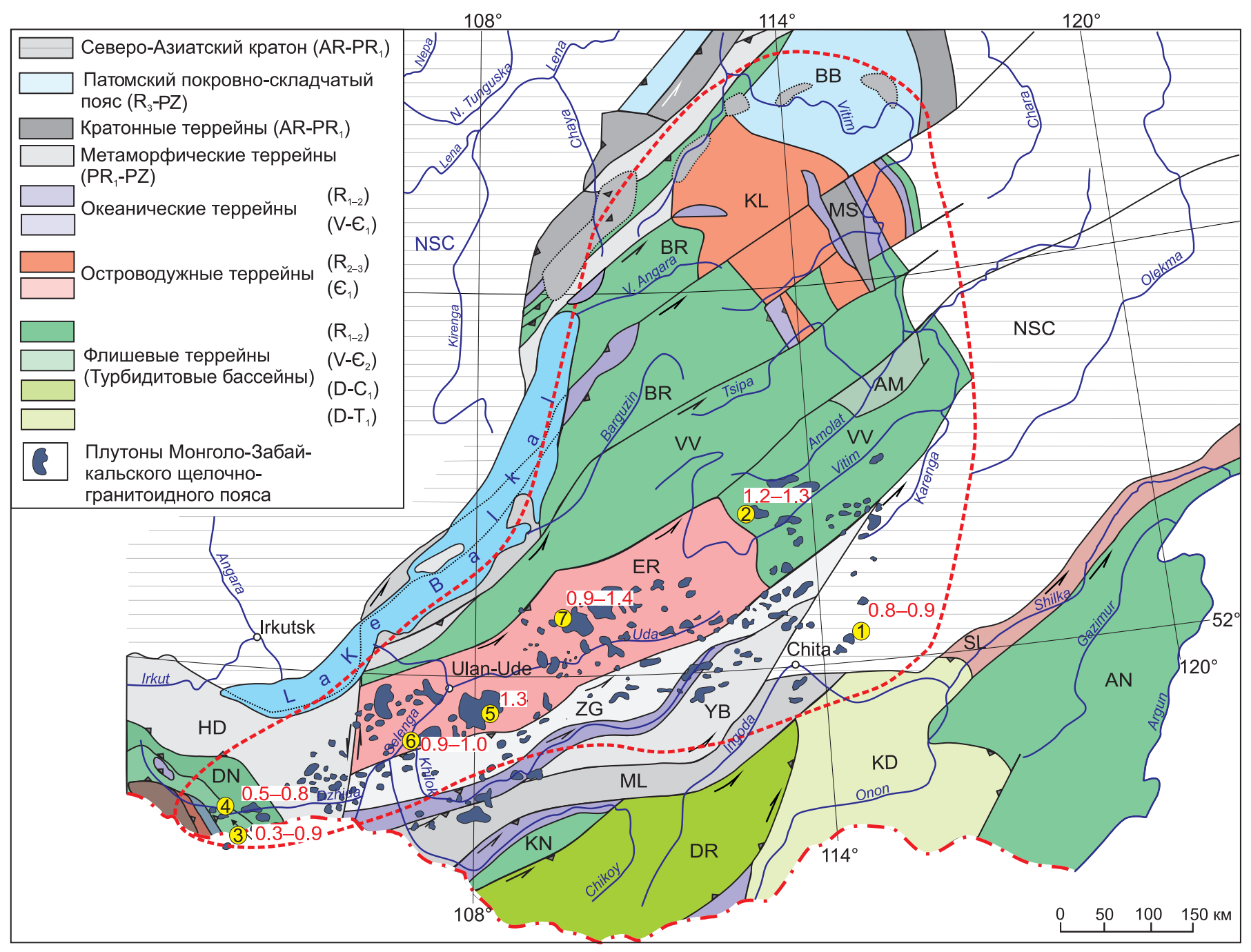

Рис. 1. Схема террейнов Саяно-Байкальской складчатой области, по [Bulgatov, Gordienko, 1999] с изменениями.

$N S C$ - Северо-Азиатский кратон. Террейны: $A M$ - Амалатский, $A N$ - Аргунский, $B B$ - Бодайбинский, $B R-$ Баргузинский, $D N-$ Джидинский, $D R$ - Даурский, $E R$ - Еравнинский, $H D-$ Хамардабанский, $K L-$ Килянский, $K N$ - Куналейский, $M L-$ Малханский, $M S-$ Муйский, $V V$ - Верхневитимский, $Y B$ - Яблоновый, $Z G$ - Заганский. Массивы: 1 - Кручининский, 2 - Шербахтинский, 3 - Шабартайский, 4 - Хамнейский (Бургуйская ВТС), 5 - Брянский, 6 - Харитоновский, 7 - Хоринский. Рядом с номером массива приведено значение модельного возраста $\mathrm{T}_{\mathrm{Nd}}(\mathrm{DM}-2)$, млрд лет. Красная пунктирная линия - контуры Ангаро-Витимского батолита.

Fig. 1. Terrane map of the Sayan-Baikal folded area (modified after [Bulgatov, Gordienko, 1999]).

$N S C$ - North Asian craton. Terranes: $A M$ - Amalat, $A N$ - Argun, $B B$ - Bodaibo, $B R$ - Barguzin, $D N$ - Dzhida, $D R$ - Dauria, $E R$ - Eravna, $H D$ Khamar-Daban, $K L$ - Kilyan, $K N$ - Kunaley, $M L$ - Malkhan, $M S$ - Muya, $V V$ - Upper Vitim, $Y B$ - Yablonovy, $Z G$ - Zagan. Massifs: 1 - Kruchininsky, 2 - Sherbakhtinsky, 3 - Shabartay, 4 - Khamney (Burguy VTS), 5 - Bryansk, 6 - Kharitonovo, 7 - Khorinsk. Model ages T Nd $_{\text {(DM- }}$ 2) (Ga) are given next to the corresponding massif numbers. A red dashed line contours the Angara-Vitim batholith.

части Монголо-Забайкальского вулканоплутонического пояса на Витимском плоскогорье в междуречье Шербахта - Джилинда (левые притоки р. Витим). Массив вытянут в северо-восточном направ-

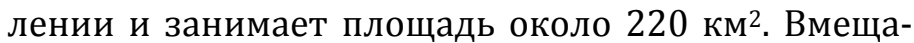
ющими породами являются позднепалеозойские граниты баргузинского комплекса, большая часть контактов с которыми осложнена разрывными нарушениями. На восточном выклинивании гранитоиды массива контактируют с гнейсами талалинской свиты предположительно протерозойского возраста. Северная часть массива перекрыта покровами четвертичных базальтов Витимского плато и современными осадками р. Джилинда.

Согласно схеме террейнов [Bulgatov, Gordienko, 1999] массив располагается в пределах Верхневитимского флишевого террейна (неопротерозойский турбидитовый бассейн), однако по другим данным [Zonenshain et al., 1990] здесь располагается Баргузинский микроконтинент с раннедокембрийским кристаллическим основанием, что, на наш взгляд, лучше согласуется с геологическими дан- 


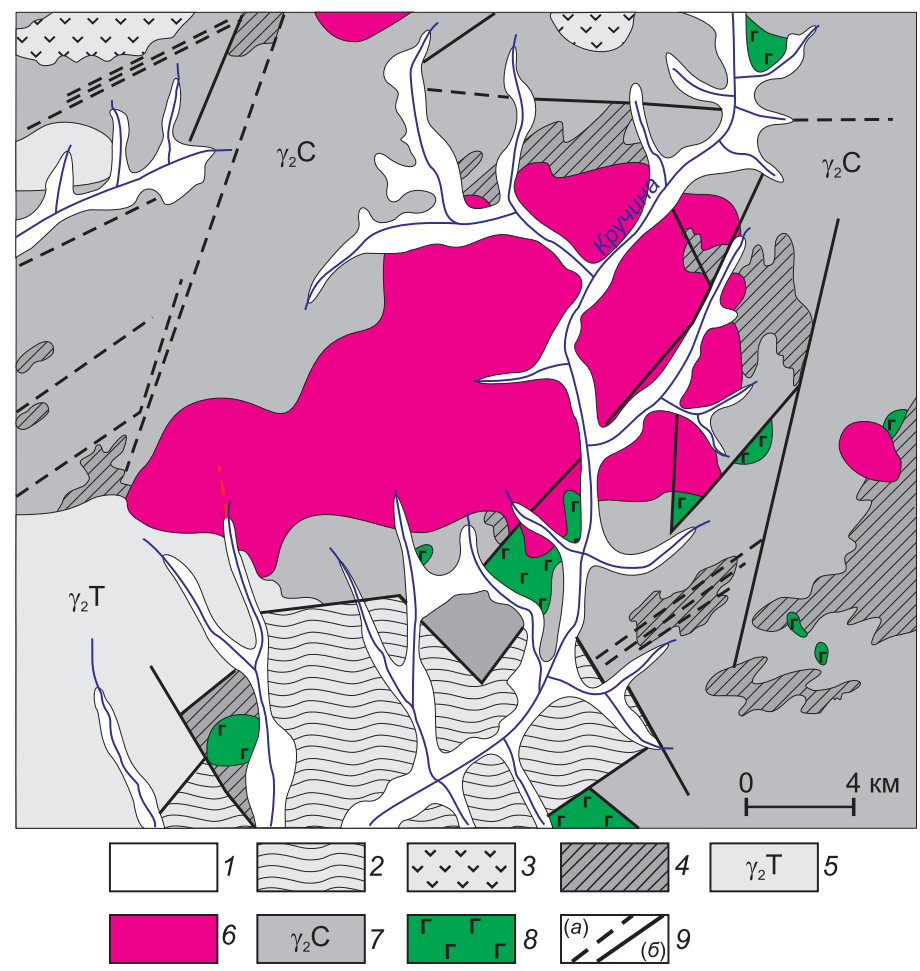

Рис. 2. Схема геологического строения Кручининского щелочно-гранитоидного плутона (Восточное Забайкалье) (составлена на основе Геологической карты СССР масштаба 1:200000, лист N-50-XXXI, с изменениями авторов).

1 - четвертичные и современные аллювиальные отложения; 2 - юрско-меловые конгломераты, гравелиты, песчаники, алевролиты; 3 - пермско-триасовые андезитовые порфириты с прослоями терригенных пород; 4 - протерозойские биотитовые, биотит-амфиболовые гнейсы и кристаллические сланцы застепинской толщи; 5 - мезозойские (Т?) граниты и гранодиориты; 6 щелочные граниты Кручининского массива; 7 - позднепалеозойские (С?) гранитоиды без расчленения; 8 - позднепалеозойские диориты, габбро-диориты и габброиды; 9 - разрывные нарушения: а - предполагаемые, б - установленные.

Fig. 2. Geological structure of the Kruchininsky alkaline-granitoid pluton (Eastern Transbaikalia) compiled on the basis of the USSR Geological Map, scale 1:200000, sheet N-50-XXXI, with the authors' changes.

1 - Quaternary and modern alluvial deposits; 2 - Jurassic-Cretaceous conglomerates, gritstones, sandstones, siltstones; 3 - PermianTriassic andesite porphyrites with interlayers of terrigenous rocks; 4 - Proterozoic biotite, biotite-amphibole gneisses and crystalline shales of the Zastepinsky sequence; 5 - Mesozoic (T?) granites and granodiorites; 6 - alkaline granites of the Kruchininsky massif; 7 - Late Paleozoic (C?) granitoids, undifferentiated; 8 - Late Paleozoic diorites, gabbro-diorites and gabbroids; 9 - faults: a - assumed, 6 - confirmed.

ными и изотопными характеристиками позднепалеозойских гранитоидов АВБ [Tsygankov, 2014], развитых в этой части Забайкалья.

Шербахтинский массив сложен двумя основными типами пород - биотитовыми сиенитами и щелочными гранитами. В резко подчиненном количестве встречаются кварцевые сиениты, по-видимому, являющиеся дифференциатами сиенитов. Каких-либо непосредственных соотношений между основными типами пород - сиенитами и гранитами - не обнаружено, поэтому они считаются фациальными разновидностями. Вместе с тем ярко выраженная дискретность состава пород массива (см. ниже) позволяет предполагать их принадлежность к разным интрузивным фазам, что в целом характерно для крупных щелочно-гранитоидных плутонов [Litvinovsky et al., 2002]. U-Pb изотопный воз- раст пород Шербахтинского массива составляет

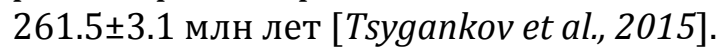

Сиениты Шербахтинского массива представляют собой серые, розовато-серые массивные среднеи крупнозернистые, иногда неясно-порфировидные $(K f s)$ породы. Они на 60-80 \% состоят из пертитового K-Na полевого шпата, плагиоклаза (олигоклаз-альбит), умеренно железистого биотита

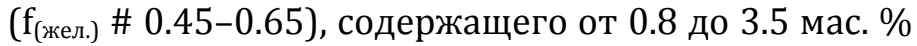
$\mathrm{TiO}_{2}$, и Са-амфибола, состав которого варьируется от магнезиальной роговой обманки (mg \# 0.410.63) до актинолита [Leake et al., 1997]. Как правило, биотит преобладает, однако в некоторых случаях соотношение биотита и амфибола примерно 1:1. Изредка, в виде реликтов в амфиболе, встречается диопсид. Для сиенитов характерен широкий набор акцессорных минералов, включающий магнетит, 


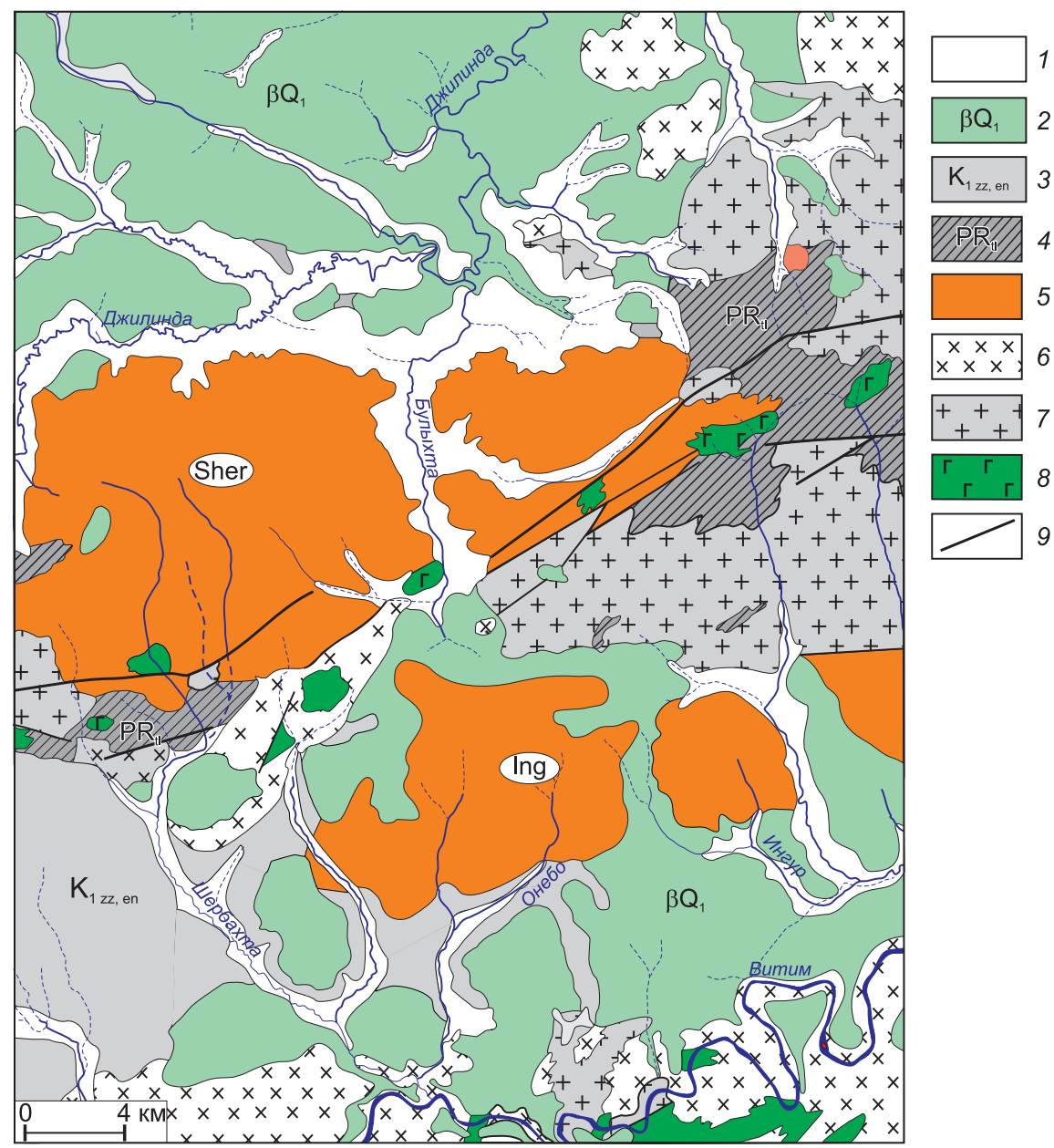

Рис. 3. Схема геологического строения Шербахтинского щелочно-гранитоидного плутона (Западное Забайкалье) (составлена на основе Геологической карты СССР масштаба 1:200000, лист N-49-XXIV, с изменениями авторов)

1 - четвертичные и современные аллювиальные отложения; 2 - четвертичные базальты; 3 - меловые континентальные отложения язинской и ендондинской свит (конгломераты, гравелиты, песчаники, пелитоморфные карбонаты); 4 - протерозойские биотит-амфиболовые гнейсы и кристаллические сланцы с прослоями кварцитов и мраморов, талалинская свита; 5 - щелочные граниты и щелочно-полевошпатовые сиениты; Ангаро-Витимский батолит: 6 - субщелочные лейкограниты зазинского комплекса, 7 - граниты баргузинского комплекса, 8 - диориты, габбро-диориты, габброиды; 9 - разрывные нарушения. Массивы: Sher - Шербахтинский, Ing - Ингурский.

Fig. 3. Geological structure of the Sherbakhtinsky alkaline-granitoid pluton (Western Transbaikalia) compiled on the basis of the USSR Geological Map, scale 1:200000, sheet N-49-XXIV, with the authors' changes.

1 - Quaternary and modern alluvial deposits; 2 - Quaternary basalts; 3 - Cretaceous continental deposits of the Yazin and Endondin suite (conglomerates, gritstones, sandstones, pelitomorphic carbonates); 4 - Proterozoic biotite-amphibole gneisses and crystalline shales with interlayers of quartzites and marbles, Talalinskaya suite; 5 - alkaline granites and alkali-feldspar syenites; Angara-Vitim batholith: 6 subalkaline leucogranites of the Zaza complex, 7 - granites of the Barguzin complex; 8 - diorites, gabbro-diorites, gabbroids, 9 - faults. Sher - Sherbakhtinsky, Ing - Ingur massifs.

ильменит, титанит, апатит, циркон, циркелит, монацит, рутил, перрьерит.

Граниты представляют собой светло-серые, желтовато- и розовато-серые средне- и крупнозернистые породы с массивной текстурой. Они на 5065 об. \% состоят из пертитового К-Nа полевого шпата, кварца (30-35 об. \%) и щелочного амфибола (железистый барруазит, винчит, рибекит) (mg \# 0.240.7), содержание которого составляет 8-10 об. \%. Железистый биотит (f \# 0.80-0.85), имеет подчи- ненное значение; эпизодически встречается сильно измененный пироксен (эгирин). К акцессорным минералам, характерным для сиенитов, добавляются флюорит, ксенотим, чевкинит, фергюссонит, эвксенит, бастнезит, Се-лантанит. К особенностям акцессорной минерализации можно отнести присутствие REE-апатита и F-апатита. Содержание REE (суммы оксидов La, Ce, Pr, Nd) в апатите достигает 7 мас. \%, содержание в нем фтора в сиенитах - до 5 мас. \%, а в гранитах - до 7 мас. \%. 


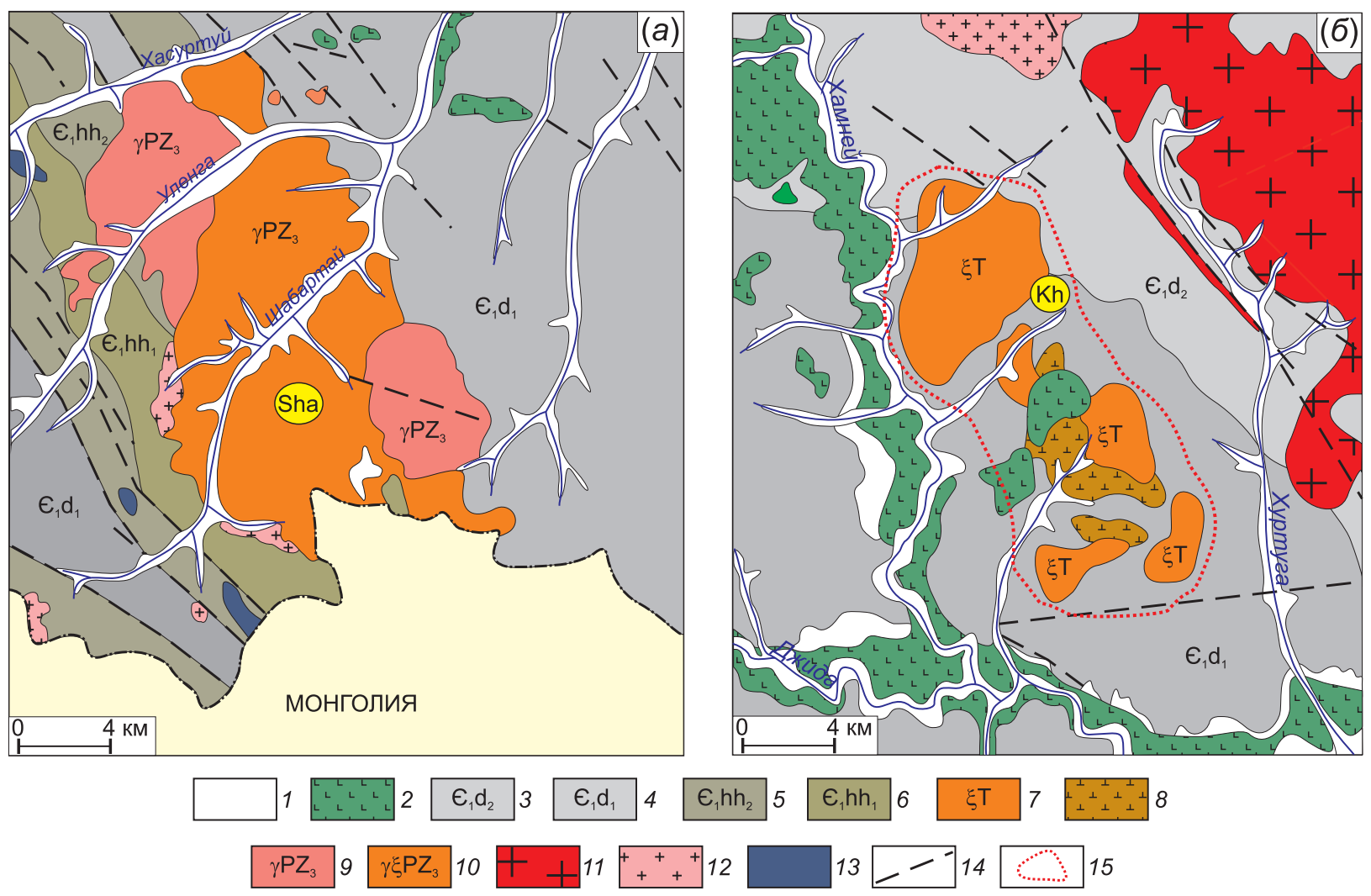

Рис. 4. Схема геологического строения Шабартайского массива (a) и Бургуйской ВТС (б), Юго-Западное Забайкалье (составлена на основе Геологической карты СССР масштаба 1:200000, лист M-48-XIV, с изменениями авторов).

1 - четвертичные и современные аллювиальные отложения; 2 - неогеновые и четвертичные базальты; 3-4 - джидинская свита нижнего кембрия: 3 - верхняя подсвита - песчаники, известняки, сланцы, 4 - нижняя подсвита - конгломераты, туфопесчаники, ритмично переслаивающиеся песчаники, известняки и сланцы; 5-6 - хохюртовская свита нижнего кембрия: 5 - верхняя подсвита - метабазальты, туфы, туфоконгломераты, метаморфические сланцы с линзами известняков и конгломератов, 6 - нижняя подсвита - известняки, кремнистые сланцы, кварциты с линзами конгломератов и порфиритов; 7-8 - Бургуйская ВТС: 7 - щелочные сиениты, 8 - лавы трахитов; 9-10 - Шабартайский массив (Sha): 9 - щелочные лейкограниты второй фазы, 10 - щелочно-полевошпатовые сиениты и граносиениты первой фазы; 11 - позднепалеозойские граниты без разделения; 12 - раннепалеозойские плагиограниты; 13 - серпентиниты; 14 - разрывные нарушения; 15 - предполагаемые контуры Хамнейского (Кh) массива.

Fig. 4. Geological structure of the Shabartay massif $(a)$ and the Burguy VTS (б), Southwestern Transbaikalia, compiled on the basis of the USSR Geological Map, scale 1:200000, sheet M-48-XIV, with the authors' changes.

1 - Quaternary and modern alluvial deposits; 2 - Neogene and Quaternary basalts; Lower Cambrian Dzhida Formation: 3 - upper subsequence - sandstones, limestones, shales; 4 - lower subsequence - conglomerates, sand tuff, rhythmically alternating sandstones, limestones, and shales; Lower Cambrian Khokhyurta Formation: 5 - upper subsequence - metabasalts, tuffs, tuff conglomerates, metamorphic shales with lenses of limestones and conglomerates, 6 - lower subsequence - limestones, siliceous shales, quartzites with lenses of conglomerates and porphyrites; Burguy VTS: 7 - alkaline syenites, 8 - trachyte lavas; Shabartay massif (Sha): 9 - second-phase alkaline leucogranites, 10 - first-phase alkaline-feldspar syenites and granosyenites; 11 - Late Paleozoic granites without dissection; 12 - Early Paleozoic plagiogranites; 13 - serpentinites; 14 - discontinuities; 15 - suggested contours of the Khamney (Kh) massif.

Шабартайский массив (рис. 4, а) расположен в бассейне р. Шабартай, правого притока р. Джида (Юго-Западное Забайкалье), в пределах раннепалеозойского Джидинского островодужного террейна. Он имеет овальную форму, с отчетливой ориентировкой в северо-западном направлении, и

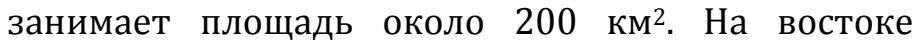
массив прорывает собранные в складки флишоидные карбонатно-терригенные отложения джидинской свиты, а на западе - венд-кембрийские вулканогенно-осадочные и магматические образования Джидотского палеогайота. Экзоконтактовые изменения выражены ореолами роговиков и скарнов.

Согласно данным изотопно-геохронологических исследований, U-Pb возраст сиенитов Шабартайского массива составляет 298 \pm 2 млн лет [Reznitsky et al., 2005], Ar-Ar возраст гранитов (биотит) $289 \pm 2.5$ млн лет [Khromova, 2008], что, с учетом более низкой температуры закрытия K-Ar изотопной 
системы и погрешностей измерения, можно считать одинаковым.

Массив сложен породами двух фаз: первая фаза представлена граносиенитами, сиенитами, монцонитами. Вторая фаза сформирована кирпичнокрасными лейкократовыми мелко- и среднезернистыми гранитами, и порфировидными гранитами. Содержание микроклин-пертита варьируется от 60 \% в гранитах до 80-90 \% в сиенитах. Содержание темноцветных минералов (биотит и роговая обманка) не превышает $10 \%$. Амфибол обычно представлен магнезиальной роговой обманкой, в сиенитах присутствует рибекит. Кроме амфиболбиотитовых сиенитов встречаются двупироксенбиотитовые разности, в которых вместо амфибола развит орто- и клинопироксен.

Бургуйская вулканотектоническая структура (рис. 4 , б) расположена в междуречье Хамней - Хуртуга, левых притоков р. Джида (Юго-Западное Забайкалье), севернее населенного пункта Бургуй. Как и Шабартайский массив, Бургуйская ВТС располагается в пределах Джидинского островодужного террейна и представлена выходами субвулканических и вулканических пород цаган-хунтейской свиты и интрузиями малокуналейского комплекса. Несколько компактно расположенных выходов интрузивных пород, площадью от 4 до 50 км², представляют, по-видимому, вскрытые эрозией апикальные части единого крупного массива, который в дальнейшем мы будем называть Хамнейским. Гранитоиды Хамнейского плутона представлены умеренно-щелочными монцонитами, сиенитами, щелочными кварцевыми сиенитами и гранитами. Возраст массива, по аналогии с подобными образованиями Забайкалья, считается среднепозднетриасовым. Изотопно-геохронологические данные отсутствуют.

Таким образом, предметом нашего рассмотрения являются четыре массива, сложенных гранитоидами повышенной и высокой щелочности, которые сформировались на зрелой континентальной коре западной части Алданского щита (Селенгино-Становой террейн), в пределах Баргузинского микроконтинента (по другим данным [Bulgatov, Gordienko, 1999] флишевого террейна) и раннепалеозойского островодужного террейна. Кроме того, в качестве эталонных объектов будут использованы геохимические данные по Брянскому [Litvinovsky et al., 2002] и Харитоновскому [Zanvilevich et $a l ., 1995]$ щелочно-гранитоидным плутонам, являющимся типоморфными для ранне- и позднекуналейского комплексов позднепалеозойского и раннемезозойского возраста соответственно [Tsygankov et al., 2010]. Оба этих массива приурочены к раннепалеозойскому Удино-Еравнинскому островодужному террейну [Bulgatov, Gordienko, 1999].

\section{3. ВЕЩЕСТВЕННЫЙ СОСТАВ}

Химический состав представительных проб рассматриваемых массивов приведен в таблице. Согласно классификационным критериям [Petrographic Code..., 2009], их состав варьируется от сиенитов и щелочных сиенитов до умеренно-щелочных и щелочных гранитов и лейкогранитов, с отклонением единичных проб в поле монцонитов. При этом достаточно отчетливо обособляются три группы пород: сиениты и щелочные сиениты, щелочные граниты и умеренно-щелочные лейкограниты. Суммарная щелочность в этом ряду варьируется от 10-12 мас. \% в сиенитах до 7-10 мас. $\% \mathrm{Na}_{2} \mathrm{O}+\mathrm{K}_{2} \mathrm{O}$ в лейкогранитах. Примерно этому же диапазону соответствует соотношение суммы щелочей и кремнезема в сиенитах и щелочных гранитах типоморфных Брянского и Харитоновского массивов. Агпаитовый индекс (NK/A) в основном лежит в диапазоне 0.85-1.00 (рис. 5, $a$ ) и лишь в отдельных пробах превышает единицу. При этом значительная часть сиенитов характеризуется значениями $\mathrm{NK} / \mathrm{A}<0.85$. Следует отметить, что для Брянского и Харитоновского плутонов характерна более высокая щелочность, минералогическим выражением которой являются щелочные амфиболы, имеющие подчиненное значение в рассматриваемых плутонах.

На диаграмме Фроста [Frost et al., 2001] сиениты лежат в щелочном поле, а граниты - в щелочноизвестковом (рис. 5, в). Рассматриваемые породы имеют высокую железистость, характерную для гранитоидов А-типа (рис. 5, б). Исключение составляют сиениты Шабартайского плутона, фигуративные точки состава которых располагаются в магнезиальном поле диаграммы. На классификационной диаграмме соотношения $\mathrm{Zr}-10000 \times \mathrm{Ga} / \mathrm{Al}$ [Whalen et al., 1987] практически все аналитические точки соответствует гранитоидам А-типа (рис. $5,2)$.

Соотношение $\mathrm{SiO}_{2}$ с некоторыми элементамипримесями (Ba, $\mathrm{Sr}, \mathrm{Rb}, \mathrm{Zr}$ ) показывает (рис. 6), что наиболее заметные отличия от равных по основности пород эталонных Брянского и Харитоновского массивов заключаются в более высоком содержании $\mathrm{SiO}_{2}$ в $P A$-гранитах рассматриваемых массивов, относительно пониженной кремнекислотности $A F S$-сиенитов и пониженном содержании Rb в гранитах. Кроме того, следует отметить, что содержание Zr в гранитах хоть и перекрывается с эталонными объектами, но, тем не менее, не превышает (кроме одной пробы) 1000 ppm, тогда как в РА гранитах Брянского и Харитоновского массивов достигает 2000 ррт и более.

Распределение REE в породах изученных массивов (рис. 7) также имеет свои особенности. В поро- 
Химический состав представительных проб гранитоидов Забайкалья А-типа, оксиды в мас. \%, элементы примеси в г/т

Chemical composition of representative rocks from A-type granitoids of Transbaikalia ( wt. \%, ppm)

\begin{tabular}{|c|c|c|c|c|c|c|c|c|c|c|c|c|}
\hline Массив & Кручини & ский & & & & & Шерба & тински & & & & \\
\hline Проба & KR-04a* & KR-05 & KR-06/1 & KR-02/2 & KR-03a* & KR-23 & Sr-52 & Sr-6b & Sr-12b & Sr-17 & $\mathrm{Sr}-13 / 2 \mathrm{a}$ & Sr-14-5 \\
\hline Порода & $P A-G r$ & $P A-G r$ & $P A-G r$ & $G r-p r$ & $G r-p r$ & $G r-p r$ & $P A-G r$ & $P A-G r$ & AFS-Sy & $A F S-S y$ & $A F S-S y$ & $A F S-S y$ \\
\hline $\mathrm{SiO}_{2}$ & 76.00 & 75.70 & 76.20 & 76.60 & 77.90 & 76.00 & 73.4 & 74.1 & 62.2 & 64 & 66.7 & 67.9 \\
\hline $\mathrm{TiO} 2$ & 0.20 & 0.20 & 0.28 & 0.15 & 0.07 & 0.19 & 0.21 & 0.33 & 0.98 & 0.7 & 0.6 & 0.59 \\
\hline $\mathrm{Al}_{2} \mathrm{O}_{3}$ & 11.90 & 12.00 & 11.40 & 12.00 & 12.40 & 12.70 & 13.4 & 12.5 & 18.1 & 17.5 & 15.7 & 14 \\
\hline $\mathrm{Fe}_{2} \mathrm{O}_{3}$ & 1.65 & 1.67 & 2.14 & 1.74 & 0.49 & 1.70 & 0.9 & 1.02 & 1.49 & 1.77 & 1.27 & 1.58 \\
\hline $\mathrm{FeO}$ & 0.28 & 0.40 & 0.32 & 0.01 & 0.01 & 0.05 & 1.0 & 1.28 & 1.88 & 1.44 & 1.6 & 2.2 \\
\hline $\mathrm{MnO}$ & 0.04 & 0.05 & 0.03 & 0.03 & 0.02 & 0.02 & 0.07 & 0.07 & 0.1 & 0.13 & 0.18 & 0.23 \\
\hline $\mathrm{MgO}$ & 0.13 & 0.16 & 0.20 & 0.08 & 0.09 & 0.13 & 0.15 & 0.15 & 0.85 & 0.52 & 0.55 & 0.54 \\
\hline $\mathrm{CaO}$ & 0.33 & 0.32 & 0.55 & 0.16 & 0.28 & 0.27 & 0.38 & 0.36 & 1.6 & 1.09 & 0.87 & 0.8 \\
\hline $\mathrm{Na}_{2} \mathrm{O}$ & 3.02 & 4.09 & 3.15 & 3.36 & 4.04 & 4.43 & 4.31 & 4.16 & 5.05 & 5.26 & 5.11 & 5.08 \\
\hline $\mathrm{K}_{2} \mathrm{O}$ & 5.55 & 4.50 & 4.69 & 5.13 & 4.48 & 4.43 & 5.17 & 4.99 & 6.61 & 6.59 & 6.27 & 4.45 \\
\hline $\mathrm{P}_{2} \mathrm{O}_{5}$ & $<0.05$ & $<0.05$ & $<0.05$ & $<0.05$ & $<0.05$ & 0.05 & 0.04 & 0.06 & 0.26 & 0.12 & 0.15 & 0.18 \\
\hline П.п.п & 0.37 & 0.62 & 0.34 & 0.30 & 0.24 & 0.34 & 0.46 & 0.54 & 0.49 & 0.33 & 0.64 & 0.66 \\
\hline Сумма & 99.48 & 99.72 & 99.31 & 99.57 & 100.03 & 100.31 & 99.49 & 99.56 & 99.61 & 99.45 & 99.64 & 99.21 \\
\hline $\mathrm{Ba}$ & 276 & 277 & 1182 & 120 & 39 & 131 & 121 & 103 & 176 & 171 & 261 & 171 \\
\hline $\mathrm{Rb}$ & 105 & 154 & 65 & 74 & 108 & 66 & 115 & 144 & 111 & 69 & 130 & 156 \\
\hline $\mathrm{Sr}$ & 54 & 47 & 355 & 26 & 14 & 17 & 28 & 21 & 32 & 52 & 43 & 34 \\
\hline Ga & 24 & 29 & 20 & 28 & 23 & 28 & 21 & 19.6 & 17.4 & 22.3 & 20.9 & 20.6 \\
\hline $\mathrm{Ta}$ & 1.54 & 1.82 & 1.71 & 0.39 & 0.91 & 0.29 & 0.93 & 1.46 & 0.29 & 0.55 & 0.90 & 0.98 \\
\hline $\mathrm{Nb}$ & 16 & 25 & 19 & 4 & 11 & 6 & 26 & 33 & 16 & 11 & 22 & 26 \\
\hline $\mathrm{Hf}$ & 33.0 & 20.0 & 23.0 & 23.0 & 4.0 & 6.2 & 13.5 & 18.8 & 1.3 & 4.4 & 8.1 & 12.1 \\
\hline $\mathrm{Zr}$ & 1166 & 634 & 720 & 479 & 77 & 252 & 455 & 608 & 502 & 601 & 424 & 507 \\
\hline Y & 76 & 73 & 82 & 63 & 8 & 8 & 24 & 40 & 39 & 24 & 54 & 43 \\
\hline $\mathrm{Th}$ & 7.8 & 8.9 & 4.4 & 6.6 & 16.0 & 5.5 & 10 & 13.6 & 1 & 8.7 & 4.1 & 6.7 \\
\hline $\mathrm{U}$ & 2.21 & 1.60 & 1.47 & 1.46 & 1.26 & 0.59 & 1.82 & 2.08 & 0.19 & 0.52 & 0.79 & 2.62 \\
\hline $\mathrm{Pb}$ & 45 & 32 & 22 & 17 & 29 & 4 & 10 & 10 & 12 & 46 & 15 & 12 \\
\hline La & 32 & 23 & 38 & 20 & 4 & 9 & 39 & 68 & 38 & 147 & 50 & 42 \\
\hline $\mathrm{Ce}$ & 98 & 81 & 93 & 57 & 18 & 29 & 91 & 142 & 75 & 297 & 132 & 112 \\
\hline $\mathrm{Nd}$ & 52 & 39 & 62 & 45 & 9 & 18 & 39 & 59 & 37 & 82 & 55 & 50 \\
\hline $\mathrm{Sm}$ & 15.0 & 11.1 & 18.0 & 13.8 & 2.2 & 3.5 & 7.4 & 10.9 & 6.4 & 12.6 & 13.9 & 11.4 \\
\hline $\mathrm{Eu}$ & 1.39 & 0.90 & 1.77 & 0.84 & 0.20 & 0.25 & 0.46 & 0.6 & 2.05 & 1.53 & 0.9 & 0.63 \\
\hline $\mathrm{Gd}$ & 16.50 & 11.40 & 17.50 & 14.40 & 1.90 & 2.78 & 6.67 & 9.76 & 5.73 & 10.97 & 13.15 & 11.06 \\
\hline $\mathrm{Tb}$ & 2.90 & 2.17 & 3.17 & 2.65 & 0.33 & 0.40 & 0.87 & 1.24 & 0.66 & 1.11 & 1.74 & 1.48 \\
\hline Dy & 17.50 & 14.40 & 19.50 & 16.50 & 2.07 & 2.28 & 4.85 & 6.56 & 3.3 & 5.02 & 9.43 & 8.07 \\
\hline Ho & 3.33 & 2.96 & 3.60 & 3.09 & 0.38 & 0.41 & 0.97 & 1.24 & 0.62 & 0.94 & 1.75 & 1.49 \\
\hline $\mathrm{Er}$ & 8.70 & 8.50 & 9.35 & 8.00 & 1.10 & 1.22 & 2.78 & 3.33 & 1.53 & 2.47 & 4.49 & 3.81 \\
\hline $\mathrm{Yb}$ & 1.14 & 8.05 & 6.75 & 6.05 & 1.08 & 1.42 & 2.59 & 3.04 & 1.15 & 1.87 & 3.42 & 3.63 \\
\hline $\mathrm{Lu}$ & 7.10 & 1.14 & 0.80 & 0.79 & 0.14 & 0.24 & 0.39 & 0.47 & 0.17 & 0.29 & 0.5 & 0.62 \\
\hline $\mathrm{Fe} \#$ & 0.88 & 0.87 & 0.86 & 0.92 & 0.74 & 0.87 & 0.92 & 0.94 & 0.79 & 0.85 & 0.83 & 0.87 \\
\hline $\mathrm{A} / \mathrm{CNK}$ & 1.03 & 0.98 & 1.01 & 1.05 & 1.03 & 1.01 & 1.0 & 0.97 & 0.98 & 0.98 & 0.94 & 0.96 \\
\hline NK/A & 0.92 & 0.97 & 0.90 & 0.92 & 0.93 & 0.95 & 0.95 & 0.98 & 0.86 & 0.9 & 0.97 & 0.94 \\
\hline $\mathrm{La} / \mathrm{Yb}_{(\mathrm{n})}$ & 3.2 & 2.1 & 4.0 & 2.4 & 2.6 & 4.8 & 10.8 & 16 & 23.5 & 56.5 & 10.5 & 8.3 \\
\hline $\mathrm{Eu} / \mathrm{Eu}^{*}$ & 0.27 & 0.24 & 0.30 & 0.18 & 0.29 & 0.24 & 0.20 & 0.17 & 1.01 & 0.39 & 0.20 & 0.17 \\
\hline
\end{tabular}

дах Шербахтинского, Хамнейского и Шабартайского плутонов оно по уровню накопления и степени дифференцированности REE практически идентично гранитоидам позднекуналейского комплекса. При этом в пироксен-биотитовых сиенитах Шабартайского плутона отмечается положительная Еu аномалия (Eu/Eu*=1.67), указывающая на сверхкотектическое содержание полевого шпата. Большинство же проанализированных проб характеризуется резко отрицательной Еu аномалией $\left(\mathrm{Eu} / \mathrm{Eu}^{*}=0.2-0.3\right)$, более глубокой в гранитах, и пре- обладанием LREE над HREE $\left(\mathrm{La} / \mathrm{Yb}_{(\mathrm{n})}=7-22\right)$. Суммарное содержание REE в сиенитах и гранитах вполне сопоставимо.

От этих параметров резко отличается Кручининский плутон. В нем, как отмечалось, нет сиенитов, а наиболее поздние образования представлены щелочными гранит-порфирами. Графики нормированного распределения REE характеризуются почти равными «плечами» с отношением $\mathrm{La} / \mathrm{Yb}_{(\mathrm{n})}$ от 2 до 4. При этом $\sum \mathrm{REE}$ в $P A$ гранитах (210-284 ppm) в разы больше, чем в гранит порфи- 
О ко н ч а н и е т а бли цы

End of the Table

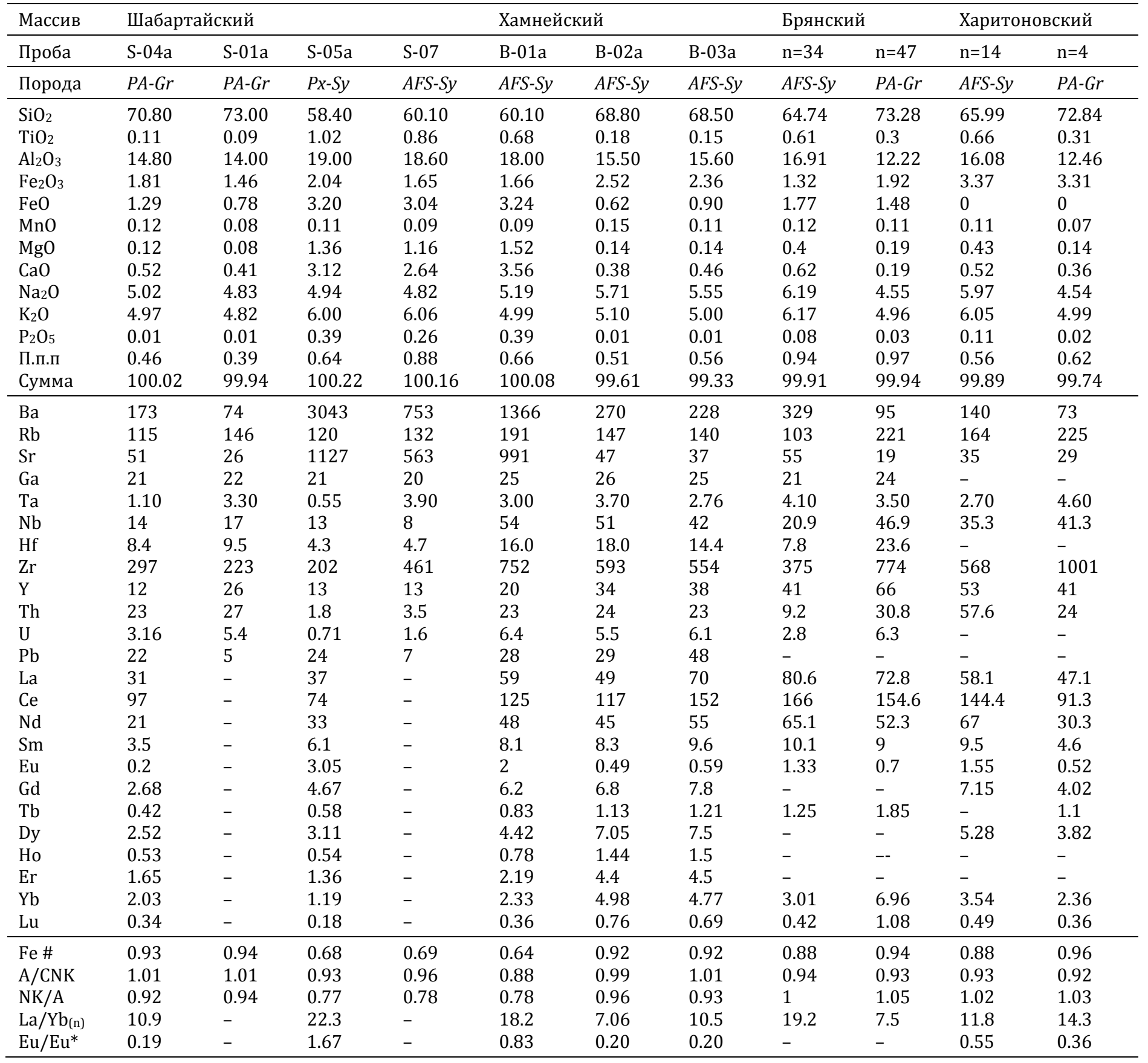

П р и м е ч а н и е. $P A-G r$ - щелочной гранит, Gr-pr - гранит-порфир, $A F S$-Sy - щелочно-полевошпатовый сиенит, $P x-S y-$ пироксеновый сиенит. Брянский и Харитоновский плутоны по [Litvinovsky et al., 2011 (Supplementary Data); Zanvilevich et al., 1995]. Fe \# $\mathrm{FeO}^{\text {tot. }} /\left(\mathrm{FeO}^{\text {tot. }}+\mathrm{MgO}\right)$, mol. \%; $\mathrm{A} / \mathrm{CNK}=\mathrm{Al}_{2} \mathrm{O}_{3} /\left(\mathrm{CaO}+\mathrm{Na}_{2} \mathrm{O}+\mathrm{K}_{2} \mathrm{O}\right)$, mol. \%; NK/A=(Na $\left.\left.2 \mathrm{O}+\mathrm{K}_{2} \mathrm{O}\right) / \mathrm{Al}_{2} \mathrm{O}_{3} ; \mathrm{Eu} / \mathrm{Eu}^{*}=\mathrm{Eu}_{\mathrm{n}} /\left(\mathrm{Sm}_{\mathrm{n}} \times \mathrm{Gd}_{\mathrm{n}}\right) 1 / 2 ;{ }^{*}\right)-\mathrm{LA}-\mathrm{ICP}-$ MS; (-) нет данных.

N o t e. $P A-G r$ - alkaline granite, $G r$ - $p r$ - granite-porphyry, AFS-Sy - alkaline feldspar syenite, $P x-S y$ - пироксеновый сиенит. Вryansk and Kharitonovo plutons (after [Supplementary Data in [Litvinovsky et al., 2011]; Zanvilevich et al., 1995]. Fe \# FeO ${ }^{\text {tot. }} /\left(\mathrm{FeO}{ }^{\text {tot. }}+\mathrm{MgO}\right), \mathrm{mol}$. \%;

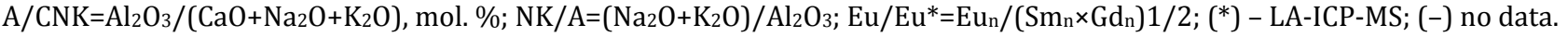

pax (43-72 ppm), при сопоставимой величине отрицательной $\mathrm{Eu}$ аномалии (0.18-0.30). Графики распределения несовместимых элементов (нормировано по среднему составу континентальной коры [Rudnick, Gao, 2003]) имеют сходный вид (рис. 8). Для них характерны отрицательные аномалии Ba, $\mathrm{Sr}, \mathrm{Eu}$, Ti, что свойственно А-гранитам, и уровень концентраций, сопоставимый с эталонными массивами.

Таким образом, петрогеохимические данные демонстрируют сходство изученных массивов как 
(a)
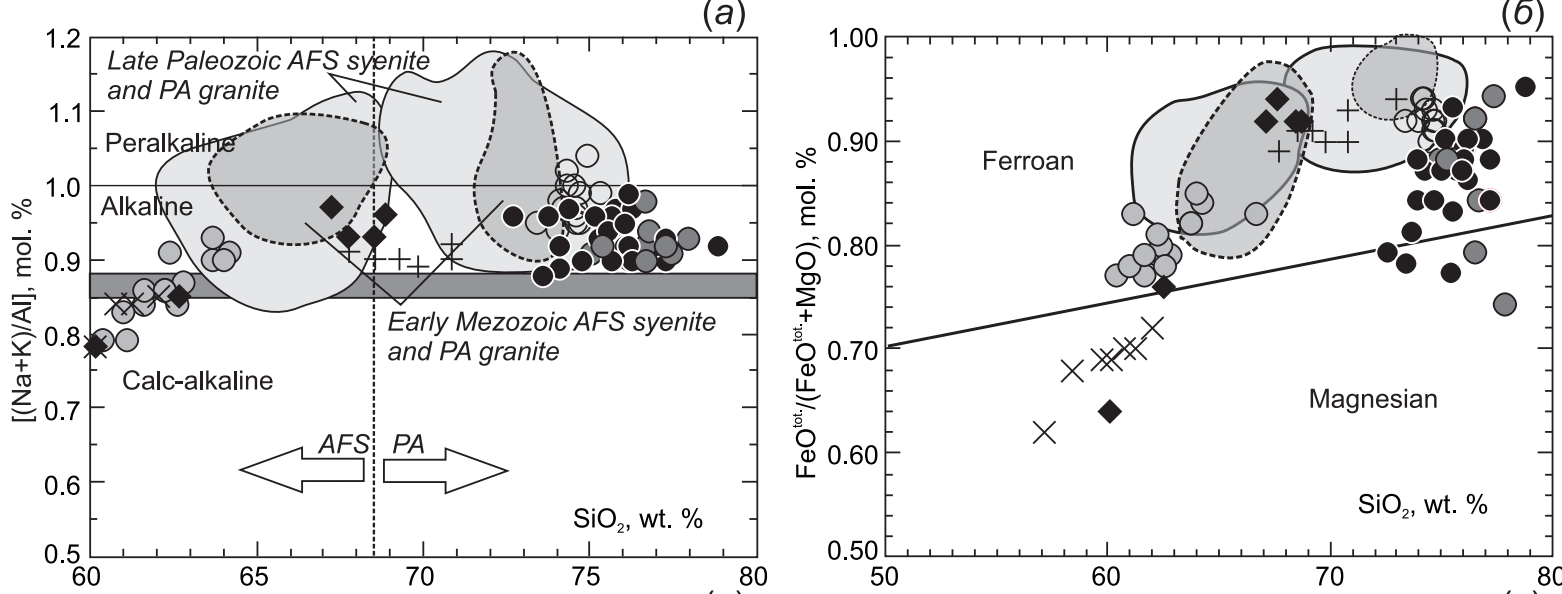

(8)
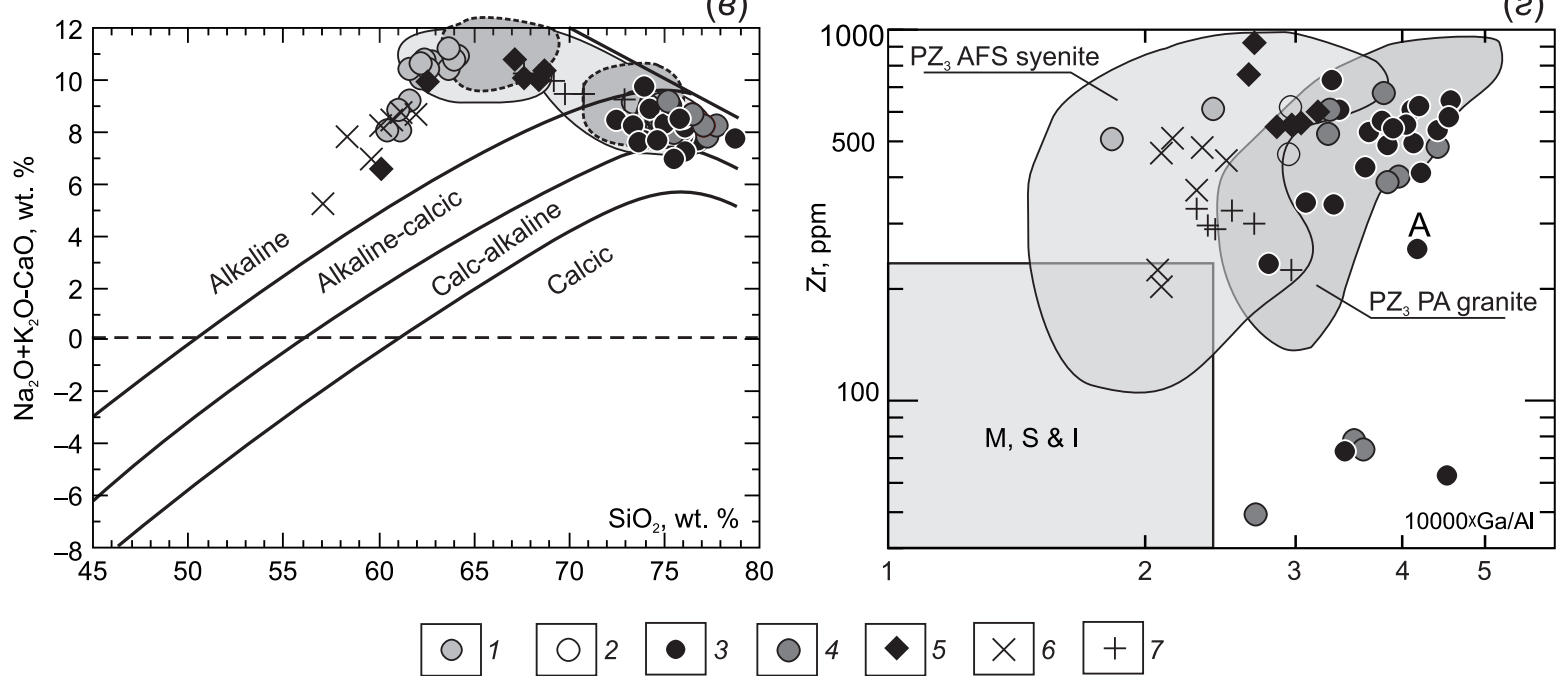

Рис. 5. Состав гранитоидов А-типа Забайкалья, показанный на классификационных диаграммах: $(a)-\mathrm{SiO}_{2}-$ $\left(\mathrm{Na}_{2} \mathrm{O}+\mathrm{K}_{2} \mathrm{O}\right) / \mathrm{Al}_{2} \mathrm{O}_{3}$, mol. \% (агпаитовый индекс), по [Liegeois, Black, 1987]; (б) $-\mathrm{SiO}_{2}-\mathrm{FeO}^{\text {tot. }} /\left(\mathrm{FeO}^{\text {tot. }}+\mathrm{MgO}\right)$, mol., линия, разделяющая поля магнезиальных и железистых гранитоидов, по [Frost C.D., Frost B.R., 2011]; (8) $-\mathrm{SiO}_{2}$-MALI (the modified alkali-lime index), по [Frost et al., 2001]; (2) - Zr - 10000×Ga/Al, по [Whalen et al., 1987]. Здесь и на рис. 6-8 серыми полями показан состав AFS-сиенитов и PA-гранитов ранне- и позднекуналейского комплексов [Litvinovsky et al., 2011].

1-2 - Шербахтинский плутон: 1 - AFS-сиениты, 2 -PA-граниты; 3-4 - Кручининский плутон: 3 - PA-граниты, 4 - PA-гранитпорфиры; 5 - AFS-сиениты Хамнейского плутона; 6-7 - Шебартайский плутон: 6 - AFS-сиениты, 7 - PA-граниты.

Fig. 5. Composition of Transbaikalia A-type granitoids demonstrated in the classification diagrams: (a) - $\mathrm{SiO}_{2}-$ $\left(\mathrm{Na}_{2} \mathrm{O}+\mathrm{K}_{2} \mathrm{O}\right) / \mathrm{Al}_{2} \mathrm{O}_{3}$, mol. \% (agpaitic index), after [Liegeois, Black, 1987]; (6) $-\mathrm{SiO}_{2}-\mathrm{FeO}^{\text {tot. }} /\left(\mathrm{FeO}^{\text {tot. }}+\mathrm{MgO}\right)$, mol., line separating the fields of magnesian and ferruginous granitoids, after [Frost C.D., Frost B.R., 2011]; ( 8 ) - $\mathrm{SiO}_{2}$ - MALI (the modified alkali-lime index), after [Frost et al., 2001]; (2) - Zr - 10000×Ga/Al, after [Whalen et al., 1987]. Here and in Fig. 6-8, gray fields indicate the composition of AFS-syenites and PA-granites of the Early and Late Kunaley complexes [Litvinovsky et al., 2011].

1-2 - Sherbakhtinsky pluton:1 - AFS-syenites, 2 - PA-granites; 3-4 - Kruchininsky pluton: 3 - PA-granites, 4 - $P A$-granite-porphyries; 5 AFS-syenites of the Khamney pluton; 6-7 - Shebartay pluton: 6-AFS-syenites, 7 - PA-granites.

между собой, так и с известными, являющимися петротипическими, массивами щелочных гранитоидов Забайкалья. Большинство диагностических параметров (щелочность, железистость, глиноземистость (A/CNK=0.98-1.08), насыщенность летучими компонентами) соответствуют гранитоидам A-типа. Очевидно, что в каждом изученном массиве имеются свои особенности, не меняющие, тем не менее, общей картины.
Данные по изотопному составу кислорода имеются лишь для Кручининского и Шербахтинского массивов: $\delta^{18} 0(\%, \mathrm{SMOW})$ в кварце щелочных гранитов Кручининского плутона составляет 5.2-6.3, в щелочных гранит-порфирах (одна проба) - 8.7, что указывает, вероятно, на существенную (доминирующую ?) роль мантийного компонента в источнике магм. Утяжеленный изотопный состав кислорода кварца гранит-порфиров может свидетель- 

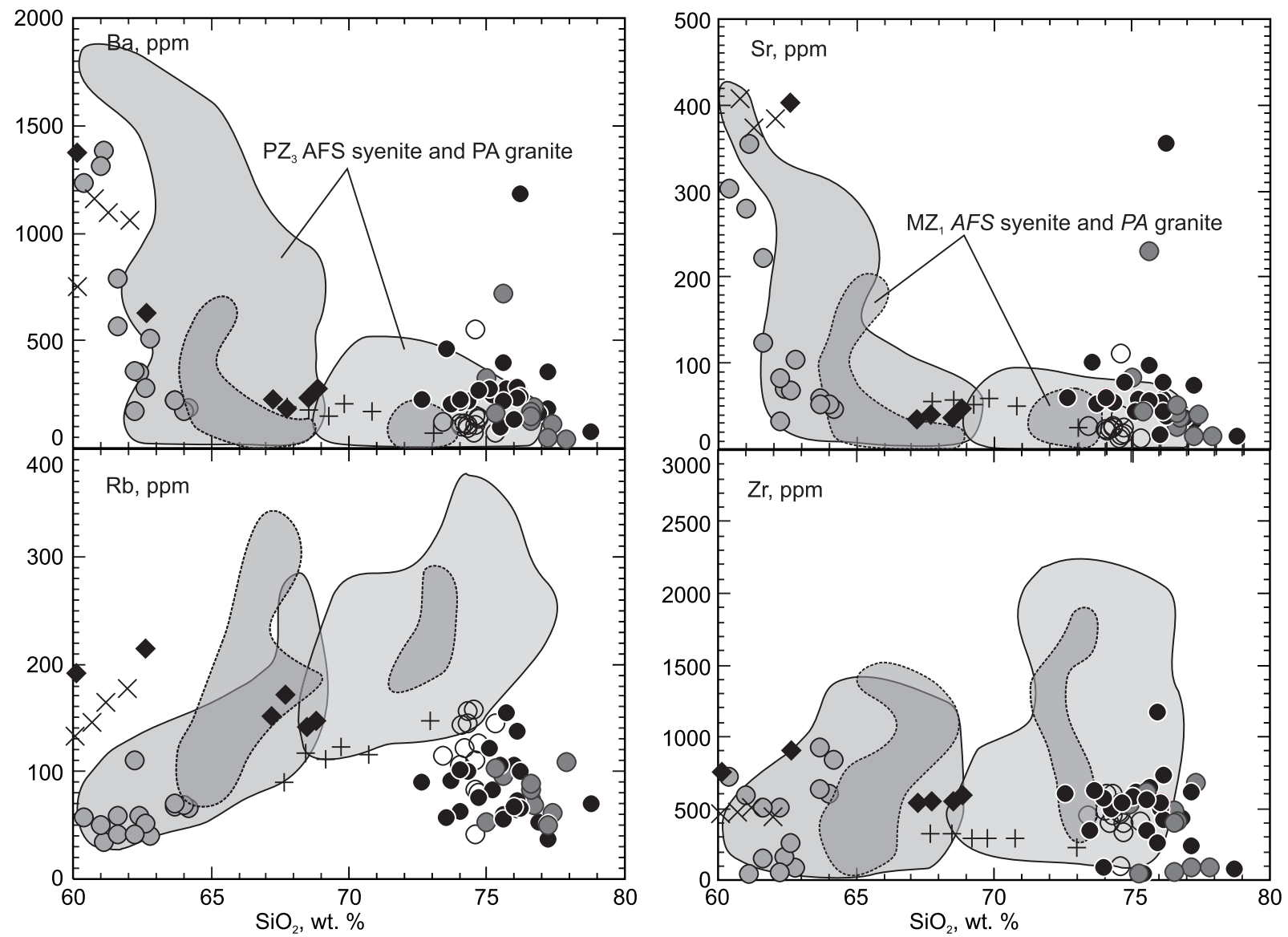

| Рис. 6. Соотношение $\mathrm{Ba}, \mathrm{Sr}, \mathrm{Rb}, \mathrm{Zr}$ c SiO 2 в гранитоидах Забайкалья А-типа. Условные обозначения см. рис. 5.

Fig. 6. $\mathrm{Ba}, \mathrm{Sr}, \mathrm{Rb}, \mathrm{Zr}$ to $\mathrm{SiO}_{2}$ ratios in Transbaikalia A-type granitoids. See Fig. 5 for the symbols.

ствовать о коровой контаминации либо об образовании расплава за счет смешанного источника.

В сиенитах Шербахтинского массива $\delta^{18} 0$ составляет 7.30-7.98 \%о в кварце, 6.61-7.94 \%о в калиевом полевом шпате; в гранитах значения $\delta^{18} 0$ в пределах погрешности измерения перекрываются с указанными выше: Qtz=7.40-8.22 \%о, Kfs=8.01$8.29 \%$. В целом близкие, практически идентичные значения $\delta^{18} 0$ в минералах $\left(\Delta \delta^{18} \mathrm{O}_{\mathrm{Qtz}-\mathrm{Kfs}}=0.04-0.22\right.$ в сиенитах и 0.64-1.37 в гранитах) указывают, вопервых, на сохранность изотопной системы и, вовторых, на присутствие мантийного компонента в источнике магм. Для сравнения укажем, что в кварце из гранитоидов как ранне-, так и позднекуналейского комплекса $\delta^{18} 0$ варьируется примерно от 6.5 до $9.0 \%$ [Litvinovsky et al., 2011].

Изотопный состав $\mathrm{Nd}$ изучен во всех рассматриваемых массивах. Кручининский плутон: $\varepsilon \mathrm{Nd}_{(\mathrm{T})}$ в щелочных гранитах 2.3-2.5 (рис. 9), двухстадийный модельный возраст $\mathrm{T}_{\mathrm{Nd}}(\mathrm{DM}-2)=811-790$ млн лет; в гранит-порфирах $\varepsilon \mathrm{Nd}_{(\mathrm{T})}=0.5, \mathrm{~T}_{\mathrm{Nd}}(\mathrm{DM}-2)=938 \mathrm{млн}$ лет. В Шербахтинском щелочно-гранитоидном массиве сиениты и граниты характеризуются идентичными значениями $\varepsilon \mathrm{Nd}_{(\mathrm{T})}$, составляющими
$-2.4 \ldots-2.7$ и $-2.8 \ldots-2.9$ соответственно, с модельным возрастом $\mathrm{T}_{\mathrm{Nd}}(\mathrm{DM}-2)=1.25-1.27$ млрд лет. К этим значениям достаточно близок и изотопный состав Hf в цирконах: $\varepsilon \mathrm{Hf}_{(\mathrm{T})}=1.1-0.6, \mathrm{~T}_{\mathrm{Hf}}(\mathrm{DM}-2)=1.02-1.05$ млрд лет (определения выполнены в лаборатории изотопной геологии Института геологии и минеральных ресурсов, Тянжин, Китай). Для сиенитов Шабартайского массива Л.3. Резницкий с соавторами (2005) приводят значения $\varepsilon \mathrm{Nd}_{(\mathrm{T})}=2.3-2.6$ и $\mathrm{T}_{\mathrm{Nd}}(\mathrm{DM}-2)=0.8$ млрд лет. К этим параметрам близки полученные нами данные по гранитам: $\varepsilon \mathrm{Nd}_{(\mathrm{T})}=1.5$, $\mathrm{T}_{\mathrm{Nd}}(\mathrm{DM}-2)=956$ млн лет. Однако пироксен-биотитовые сиениты отличаются кардинально. Значение $\varepsilon \mathrm{Nd}_{(\mathrm{T})}$, рассчитанное на возраст 300 млн лет, составляет 9.3, $\mathrm{T}_{\mathrm{Nd}}(\mathrm{DM}-2)=306$ млн лет. Следует отметить, что столь высокое значение $\varepsilon \mathrm{Nd}_{(\mathrm{T})}$ в сиенитах, соответствующее параметрам деплетированной мантии, является уникальным для рассматриваемого региона и времени образования, что пока не находит приемлемого объяснения и нуждается в подтверждении на более представительном материале. Хамнейский массив: $\varepsilon \mathrm{Nd}_{(\mathrm{T})}$ в сиенитах $5.7-$ 6.7, $\mathrm{T}_{\mathrm{Nd}}(\mathrm{DM}-2)=536-459$ млн лет; в кварцевом сиените $\varepsilon \mathrm{Nd}_{(\mathrm{T})}=1.9, \mathrm{~T}_{\mathrm{Nd}}(\mathrm{DM}-2)=856$ млн лет. Отметим, 

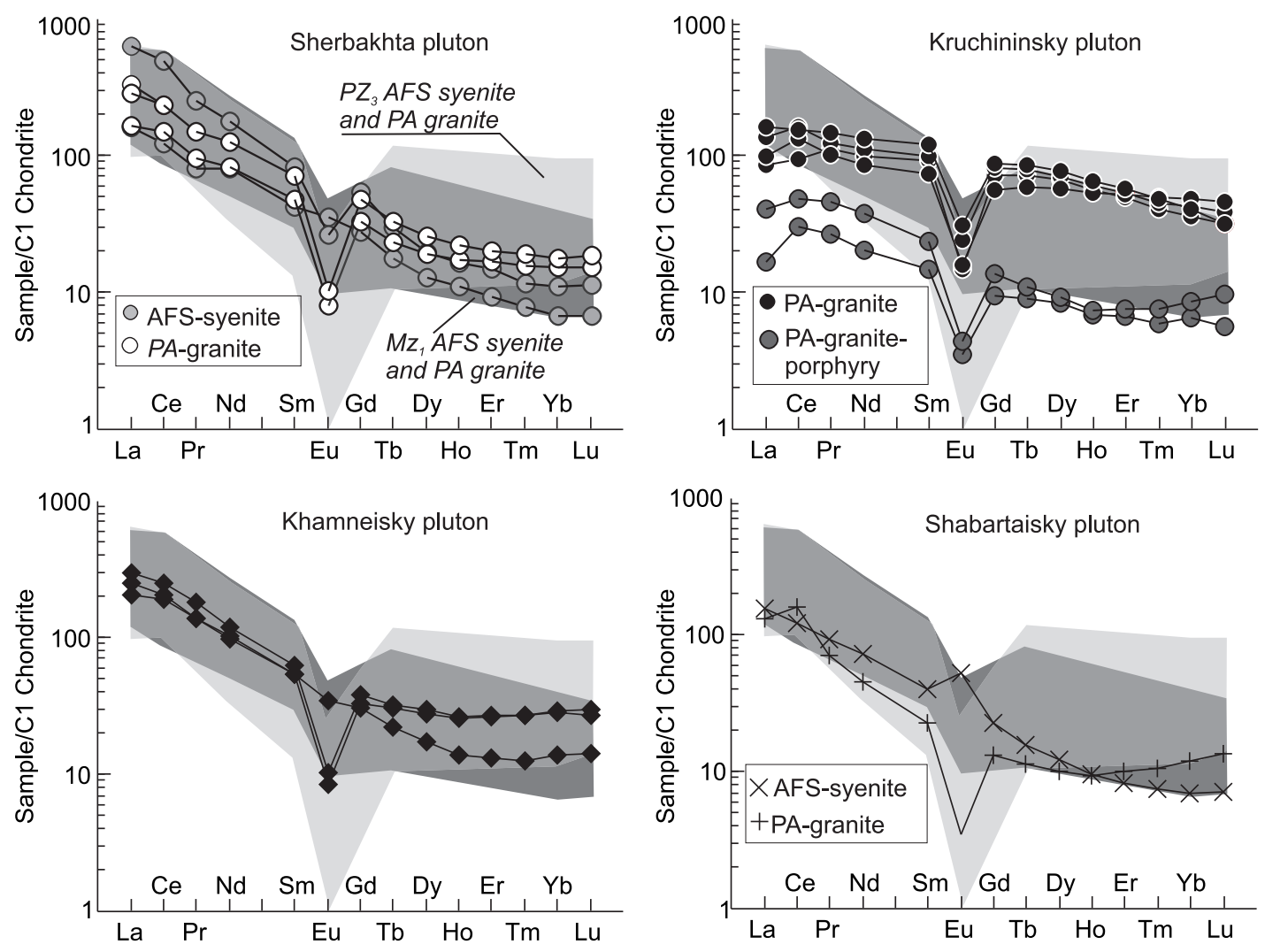

Рис. 7. Нормированное по хондриту [Sun, McDonough, 1989] распределение редкоземельных элементов в гранитоидах Забайкалья А-типа. Здесь и на рис. 8 серыми полями показан редкоземельный состав $A F S$-сиенитов и $P A$ гранитов ранне- и позднекуналейского комплексов, по [Litvinovsky et al., 2011].

Fig. 7. Chondrite-normalized REE distribution [Sun, McDonough, 1989] in Transbaikalia A-type granitoids. Here and in Fig. 8, gray fields show the rare earth composition of $A F S$-syenites and $P A$-granites of the Early and Late Kunaley complexes, after [Litvinovsky et al., 2011].

что для типоморфных разностей пород раннекуналейского комплекса характерны слабоотрицательные значения $\varepsilon \mathrm{Nd}_{(\mathrm{T})}$, составляющие примерно $-4 \ldots 0$, $\mathrm{T}_{\mathrm{Nd}}(\mathrm{DM}-2) \approx 1.2-1.4$ млрд лет, тогда как позднекуналейский комплекс характеризуется положительными $\varepsilon \mathrm{Nd}_{(\mathrm{T})}$, варьирующимися от 1 до 4 , при $\mathrm{T}_{\mathrm{Nd}}(\mathrm{DM}-2)=0.8-1.2$ млрд лет [Litvinovsky et al., 2011]. Для сравнения на рис. 9 показаны новые изотопные данные, полученные по Хоринскому щелочногранитоидному плутону (280 млн лет [Reichow et al., 2010]), принадлежащему к ранне-куналейскому комплексу, и ассоциирующим вулканогенным образованиям. Значения $\varepsilon \mathrm{Nd}_{(\mathrm{T})}$ и $\mathrm{T}_{\mathrm{Nd}}(\mathrm{DM}-2)$ (млрд лет) составляют: щелочной сиенит 0.14 и 1.05; лейкогранит -1.89 и 1.2; щелочной гранит 1.85 и 0.9 ; субвулканический сиенит-порфир -3.18 и 1.3; трахибазальт -0.16 и 1.08.

\section{4. ИЗОТОПНЫЙ ВОЗРАСТ}

Для определения $\mathrm{U}-\mathrm{Pb}$ изотопного возраста цирконов из пород Кручининского массива ото- браны пробы Kr-04-17 щелочных гранитов и Kr-0317 гранит-порфиров, состав которых приведен в таблице. Определения выполнены LA-ICP-MS методом в ЦКП «Аналитический центр минералогогеохимических и изотопных исследований» ГИН СО РАН (г. Улан-Удэ). Детали аналитической процедуры и параметры измерения приведены в работе [Khubanov et al., 2016]. Цирконы в пробе Kr-04-17 представлены прозрачными короткопризматическими кристаллами размером 150-300 мкм отношение Th/U=0.51-0.92 (рассчитано относительно ${ }^{232} \mathrm{Th} /{ }^{238} \mathrm{U}$ отношения в эталоне циркона 91500), что соответствует цирконам магматического происхождения. Некоторые точки обнаруживают сильную дискордантность, вероятно связанную с наличием нерадиогенного свинца (рис. 10, a). Средневзвешенный возраст, рассчитанный по отношению ${ }^{206} \mathrm{~Pb} /{ }^{238} \mathrm{U}$ и скорректированный по ${ }^{207} \mathrm{~Pb}$, составляет 201.6 \pm 1.4 млн лет, MSWD=1.5 (рис. 10, б). Цирконы из пробы Kr-03-17 (гранит-порфир) представлены дипирамидальными прозрачными или желтоватыми кристаллами размером 140-180 мкм. Отношение $\mathrm{Th} / \mathrm{U}=0.68-0.97$, что соответствует цирко- 
A.A. Tsygankov et al.: Correlation between the mantle and heterochronous crustal materials...
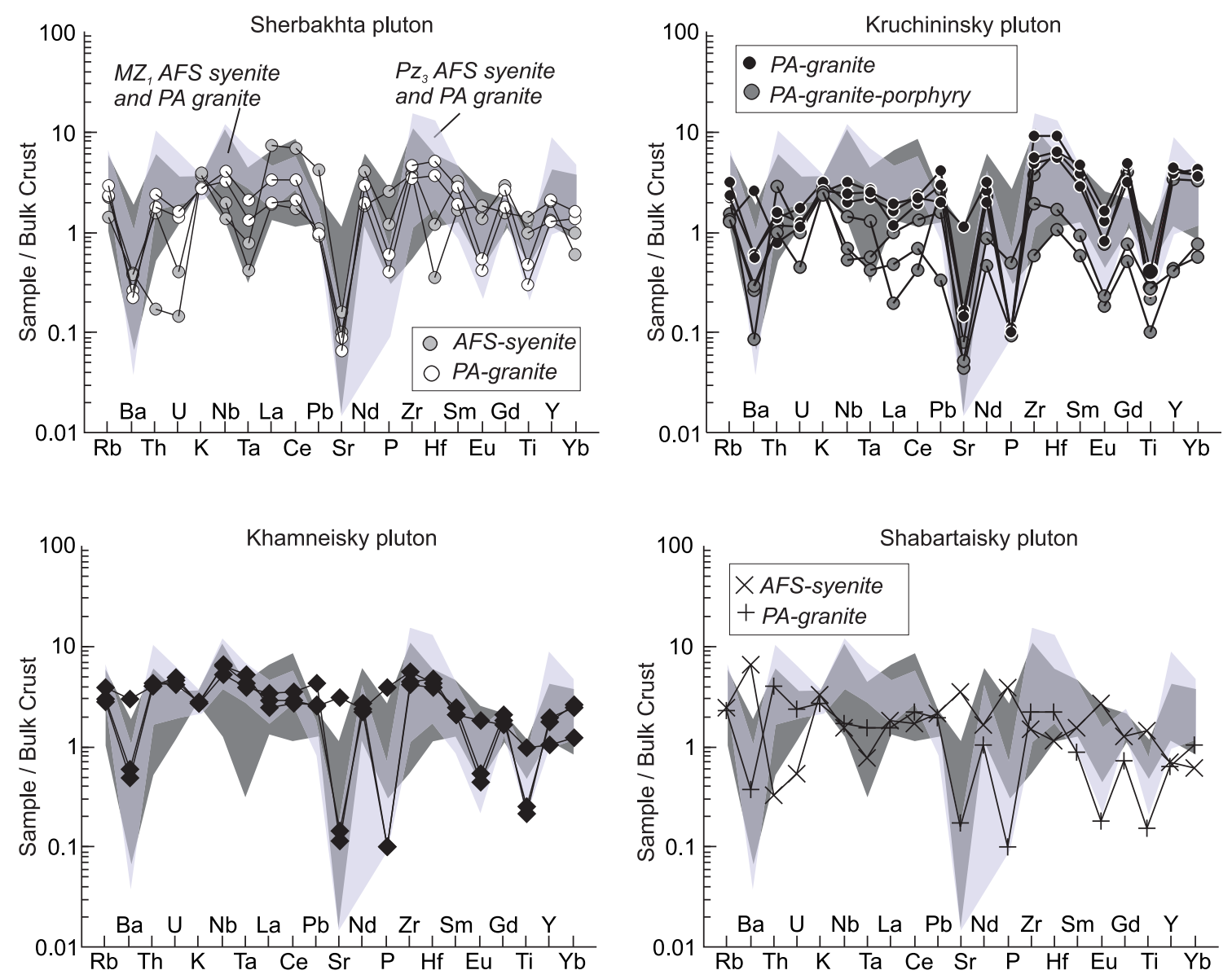

Рис. 8. Нормированные по средней континентальной коре [Rudnic, Gao, 2003] спайдер-диаграммы для гранитоидов Забайкалья А-типа.

Fig. 8. Crust-normalized spider diagrams [Rudnic, Gao, 2003] for Transbaikalia A-type granitoids.

нам магматического происхождения. Значительное количество аналитических точек отклоняется от конкордии в правую часть диаграммы (рис. 10, в), что также связано, скорее всего, с присутствием нерадиогенного свинца, поэтому нами принят средневзвешенный возраст, рассчитанный по от-

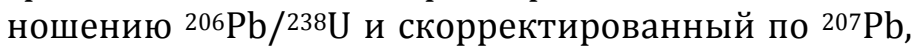
который составляет 171.1 1.1 млн лет, MSWD=1.05 (рис. 10,2 ). Полная таблица измеренных U-Th-Pb изотопных отношений и возрастов доступна по запросу к первому автору.

\section{5. ОБСУЖДЕНИЕ}

\section{1. ИСТОЧНИКИ МАГМ}

Представленные выше данные показывают, что рассматриваемые массивы щелочных гранитоидов сформировались в разных геодинамических условиях, крайними вариантами которых являются структуры западной части Алданского щита, представляющие древнюю континентальную кору, и каледонские островодужные террейны с существенно ювенильной корой. Независимо от возраста и палеогеодинамического положения рассматриваемые плутоны сложены примерно одним и тем же набором пород: это щелочно-полевошпатовые сиениты и щелочные граниты, к которым могут добавляться кварцевые сиениты или монцонитоиды. Различия заключаются лишь в объемных соотношениях главных типов пород: в одних случаях абсолютно доминирует какой-либо один тип (сиениты в Хамнейском массиве), в других - имело место пульсационное внедрение сиенитовых и щелочногранитных магм, как, например, в Брянском плутоне [Litvinovsky et al., 2002]. При этом сиениты во всех известных случаях являются более ранними.

Макро- и микроэлементный состав одноименных пород разных массивов, при наличии определенных «индивидуальных» особенностей, тем не менее, не обнаруживает кардинальных различий. Наибольшей контрастностью характеризуется изотопный состав. Прежде всего, речь идет об изотопном составе $\mathrm{Nd}$, поскольку по другим изотопным системам данные пока не полные. 


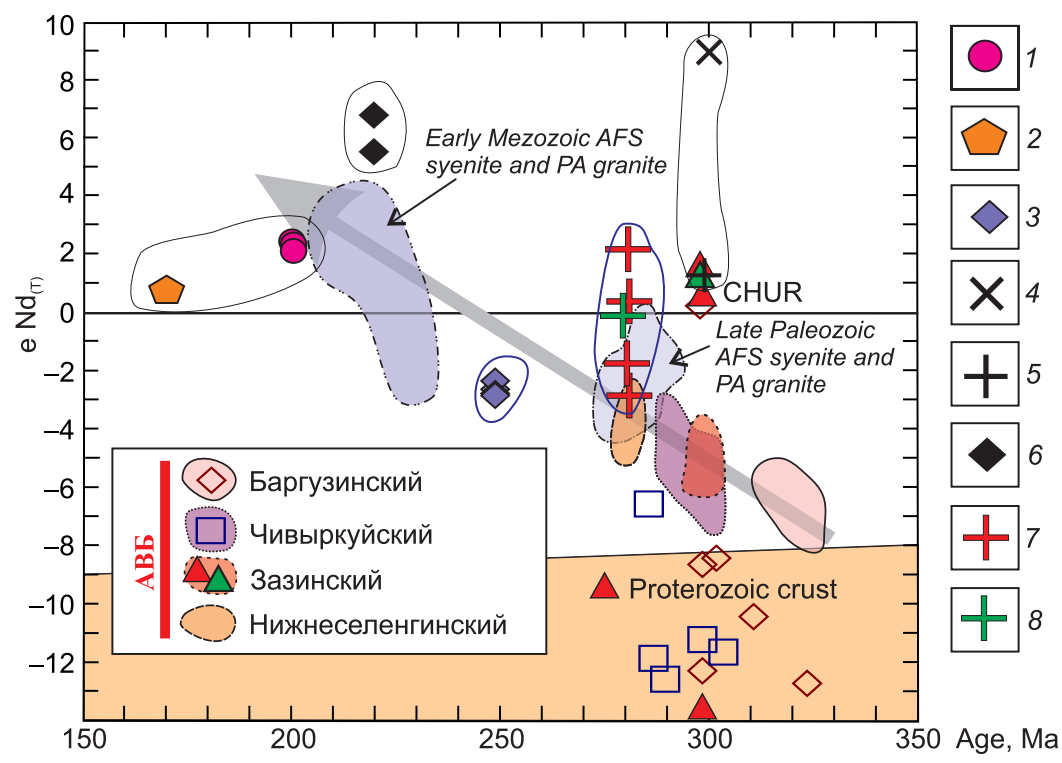

Рис. 9. Зависимость изотопного состава $\mathrm{Nd}\left(\varepsilon \mathrm{Nd}_{(\mathrm{T})}\right)$ от возраста гранитоидов Забайкалья А-типа.

1-2 - Кручининский массив: 1 - PA-граниты, 2 - гранит-порфиры; 3 - щелочные граниты Шербахтинского массива; 4-5 - Шабартайский массив: 4 - AFS-сиениты, 5 - PA-граниты; 6-AFS-сиениты Хамнейского массива; 7-8 - Хоринская вулканоплутоническая ассоциация: 7 - позднепалеозойский комплекс PA-гранитов и AFS-сиенитов, 8 - трахибазальтов. АВБ - Ангаро-Витимский батолит (баргузинский, чивыркуйский, зазинский, нижнеселенгинский комплексы), по [Litvinovsky et al., 2011], с авторскими дополнениями. Стрелкой показано направление изотопной эволюции гранитоидов Забайкалья в позднем палеозое - раннем мезозое.

Fig. 9. Dependence of the $\mathrm{Nd}\left(\varepsilon \mathrm{Nd}_{(\mathrm{T})}\right)$ isotopic composition on the age of Transbaikalia A-type granitoids.

1-2 - Kruchininsky massif: 1 - PA-granites, 2 - granite-porphyries; 3 - alkaline granites of the Sherbakhtinsky massif; 4-5 - Shabartay massif: 4 - AFS-syenites, 5 - PA-granites; 6 - AFS-syenites of the Khamney massif; 7-8 - Khorinsk volcano-plutonic association: 7 - Late Paleozoic complex of $P A$-granites and $A F S$-syenites, 8 - trachybasalts. ABБ - Angara-Vitim batholith (Barguzin, Chivyrkuy, Zaza, Lower Selenga complexes), after [Litvinovsky et al., 2011], with the author's additions. An arrow shows the direction of the isotope evolution of Transbaikalia granitoids in the Late Paleozoic - Early Mesozoic.

Выше было показано, что $\varepsilon \mathrm{Nd}_{(\mathrm{T})}$ широко варьируется как между массивами, так и в разных породах одного массива. Так наиболее низкие отрицательные значения $\varepsilon \mathrm{Nd}_{(\mathrm{T})}$, до -4 , зафиксированы в Брянском плутоне [Litvinovsky et al., 2011], а наиболее высокие, до +9, - в пироксен-биотитовых сиенитах Шабартайского массива. В одних массивах изотопный состав $\mathrm{Nd}$ в доминирующих разновидностях пород практически не различается, как, например, в Шербахтинском массиве (см. рис. 9), в других (Хоринский, Шабартайский) различия значительно превосходят аналитическую погрешность. Из этого следует, что в формировании ряда массивов принимали участие магмы, образованные за счет разных источников. Так, в Хоринском вулканоплутоническом комплексе по изотопным данным можно выделить три изотопно-геохимических типа магм, образовавших щелочные сиениты как продукт дифференциации трахибазальтов, ассоциация (?) сиенит-порфиров и лейкогранитов и щелочные граниты. В Шабартайском массиве, характеризующемся наиболее контрастным изотопным составом, также можно предполагать самостоятельный источник для пироксен-биотитовых сие- нитов с одной стороны и амфиболовых сиенитов лейкогранитов с другой.

В целом, изотопные данные фиксируют мантийную составляющую в составе всех рассматриваемых плутонов, однако ее доля и, по-видимому, происхождение, сильно различаются. Так, для раннекуналейского комплекса (Брянский массив) с модельным возрастом около 1.5 млрд лет это были скорее всего рифейские метабазиты фундамента Баргузинского микроконтинента. В Шабартайском плутоне, где модельный возраст пироксен-биотитовых сиенитов практически равен изотопному, a $\varepsilon \mathrm{Nd}_{(\mathrm{T})}$ указывает на деплетированную мантию в качестве источника расплава, можно предполагать непосредственную дифференциацию исходного базитового расплава. Во всех остальных случаях изотопный состав пород определяется сочетанием двух ведущих факторов: а) разными пропорциями мантийной и коровой составляющих в источнике магм; б) разным возрастом корового протолита. Кроме того, дополнительную неопределенность вносит околонулевой изотопный состав базитов, отражающий, по-видимому, обогащенный состав мантийного источника, поскольку эта геохимиче- 
A.A. Tsygankov et al.: Correlation between the mantle and heterochronous crustal materials...
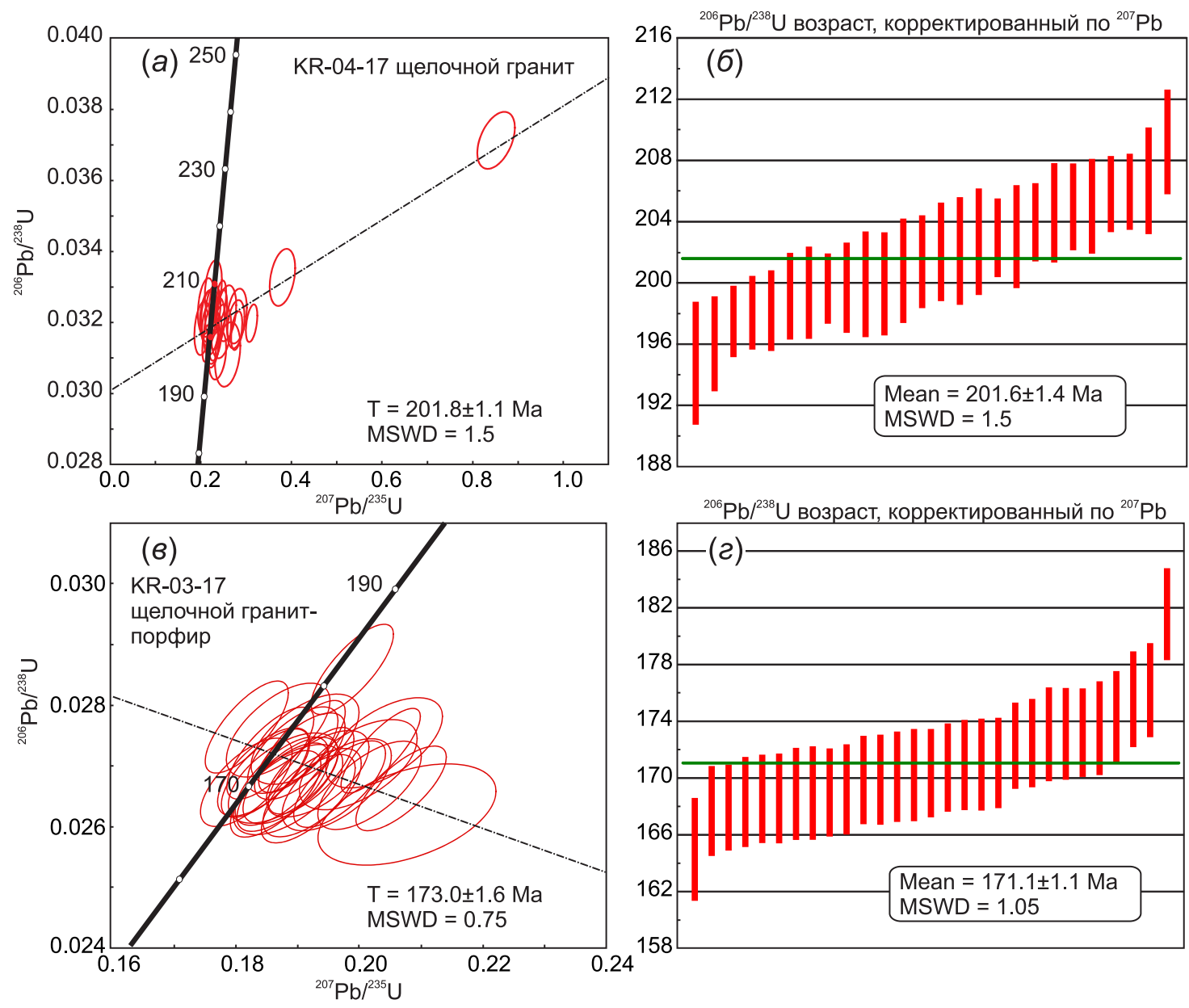

${ }^{206} \mathrm{~Pb} /{ }^{238} \mathrm{U}$ возраст, корректированный по ${ }^{207} \mathrm{~Pb}$

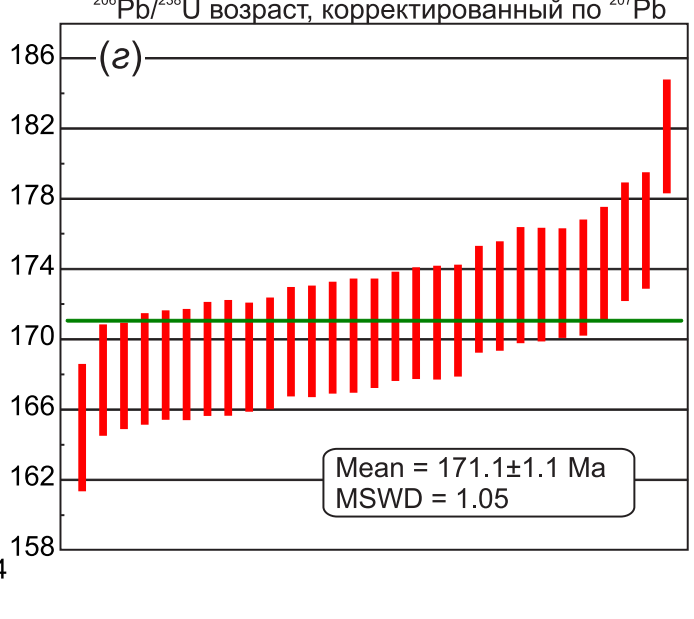

Рис. 10. U-Pb возраст цирконов из щелочных гранитов $(a)$, (б) и гранит-порфиров (в), (2) Кручининского массива. $(a)-(в)$ - графики с изотопными отношениями ${ }^{207} \mathrm{~Pb} /{ }^{235} \mathrm{U}$ и ${ }^{206} \mathrm{~Pb} /{ }^{238} \mathrm{U}$ и конкордией, построенные методом пересечения; (б)-(2) - средневзвешенный возраст по отношению ${ }^{206} \mathrm{~Pb} /{ }^{238} \mathrm{U}$, скорректированный на обыкновенный свинец методом ${ }^{207} \mathrm{~Pb}$ коррекции.

Fig. 10. U-Pb age of zircons from alkaline granites $(a)$, (б) and granite porphyries ( $($ ) $)$, (2) of the Kruchininsky massif. (a)-( $(b)$ - diagrams with ${ }^{207} \mathrm{~Pb} /{ }^{235} \mathrm{U}$ and ${ }^{206} \mathrm{~Pb} /{ }^{238} \mathrm{U}$ isotopic ratios and concordia, constructed using the intersection method; (б)-(2) - average weighted ${ }^{206} \mathrm{~Pb} /{ }^{238} \mathrm{U}$ age, corrected to ordinary lead by the $\mathrm{Pb}^{207}$ method.

ская особенность характерна для всего МонголоЗабайкальского региона [Yarmolyuk et al., 1998, 2014; Tsygankov et al., 2010; Litvinovsky et al., 2011; Tsygankov, 2014].

\section{2. ХАРАКТЕР ВЗАИМОСВЯЗИ СИЕНИТОВЫХ И ГРАНИТНЫХ РАСПЛАВОВ А-ТИПА}

Особую петрологическую проблему составляет соотношение щелочных гранитов и щелочно-полевошпатовых сиенитов, участвующих в строении крупных многофазных плутонов. Взаимосвязь этих двух главных типов пород несомненна. Они в разных соотношениях слагают многие массивы, имеют близкий (одинаковый в пределах ошибки измерения) изотопный возраст и сходные минералогогеохимические характеристики. При этом сиениты всегда предшествуют гранитам, а в изотопном со- ставе гранитов фиксируется большая доля корового компонента. Очевидно, что дифференциация сиенитовых магм не может обеспечить наблюдаемый изотопный сдвиг. Более вероятным представляется смешение сиенитовых (трахитовых) магм с мантийными или корово-мантийными изотопными метками, с чисто коровыми гранитоидными выплавками, с последующей дифференциацией гибридных магм. Сиениты, особенно щелочно-полевошпатовые, не могут образоваться за счет плавления каких-либо коровых протолитов, включая субщелочные метабазальты (см. обзор экспериментальных данных в работе [Chen, Grapes, 2007]). Скорее всего, сиениты являются продуктами фракционной кристаллизации субщелочных или щелочных базальтов, с той или иной долей ассимилированного корового материала [Khubanov et al., 2015]. 


\section{3. ГЕОДИНАМИКА}

Внутриплитный характер щелочно-гранитоидного магматизма Забайкалья не вызывает особых сомнений. Вместе с тем остается непонятным столь длительный период формирования гранитоидов Атипа в Забайкалье. Начавшись примерно 295 млн лет назад, на завершающем этапе формирования АВБ гранитоидный магматизм А-типа с перерывами продолжался до середины мела, т.е. более 170 млн лет. Очевидно, что интенсивность магматизма в течение этого времени была разной, и это нашло отражение в выделении трех этапов $(295-270,230-$ 190 и 150-120 млн лет [Jahn et al., 2009]). Возрастные ограничения этих этапов, в свете новых данных требуют как минимум корректировки, однако более важным представляется тот факт, что столь длительная магматическая активность не могла быть связана с каким-то одним геодинамическим фактором (субдукцией, плюмом, деламинацией). Следует подчеркнуть, что плутонические образования, в том числе гранитоиды, моложе примерно 120 млн лет, в Западном Забайкалье не известны. Однако, начиная примерно со 160 млн лет назад, магматическая деятельность в регионе сконцентрировалась в многочисленных грабенах, где происходили излияния лав повышенной щелочности от щелочных и субщелочных базальтов, тефритов и фонолитов до комендитов и пантеллеритов. На основании детального изучения вулканогенного выполнения грабенов Тугнуйско-Хилокского сектора Западно-Забайкальской рифтовой области с поздней юры по олигоцен включительно выделено десять сближенных этапов вулканической деятельности [Vorontsov, Yarmolyuk, 2007], в течение которых происходило постепенное сокращение доли салических пород, вплоть до их полного исчезновения.

Таким образом, Западное Забайкалье с конца карбона и по олигоцен включительно было ареной практически не прекращающегося магматизма, эволюционировавшего от исключительно корового гранитоидного (баргузинский комплекс АВБ) [Tsygankov, 2014; Tsygankov et al., 2017] до чисто мантийного (кайнозойские базальтоиды) [Vorontsov, Yarmolyuk, 2007]. Столь длительная магматическая активность, возможно, связана с тем, что южное складчатое обрамление Сибирского кратона (Забайкалье, Северная Монголия) в течение всего этого времени находилось в области горячего поля мантии, испытывая при этом вращательное движение, что косвенно подтверждается возрастными соотношениями и расположением крупнейших в Центральной Азии гранитоидных батолитов (Ангаро-Витимского, Хангайского и Хэнтей-Даурского) [Yarmolyuk et al., 2013].
При этом, как показано выше, одним из факторов вариаций изотопного состава разновозрастных гранитоидов является разная степень инкорпорирования мантийного материала в процесс гранитообразования. Очевидно, что изменения условий эволюции мафических (мантийных) магм и их взаимодействия с континентальной корой и салическими расплавами, образующимися при ее плавлении, связаны, в том числе, с возможностью проникновения мантийных магм в нижнюю и среднюю кору в область генерации гранитоидных расплавов А-типа. Проницаемость коры зависит, в первую очередь, от ее реологического состояния и характера (сжатие - растяжение) доминирующих напряжений, т.е. контролируется геодинамической обстановкой. В Западном Забайкалье становление крупнейшего Ангаро-Витимского гранитоидного батолита, судя по имеющимся геохронологическим данным [Tsygankov et al., 2017 и ссылки в этой работе], началось на завершающей стадии герцинской орогении [Ruzhentsev et al., 2012] в обстановке регионального сжатия под воздействием мантийного плюма [Yarmolyuk et al., 1997]. Предполагается [Tsygankov et al., 2017], что утолщенная, разогретая в процессе складчато-надвиговых деформаций и, соответственно, относительно пластичная нижняя и средняя кора молодого орогена была плохо проницаема для «плюмовых» магм. Их воздействие на континентальную литосферу ограничивалось дополнительным разогревом нижней - средней коры с образованием авто- и аллохтонных гранитов раннего этапа формирования АВБ (325-305 млн лет) [Tsygankov et al., 2007].

Поступление мантийных магм на верхние гипсометрические уровни коры, в форме «автономных» габбро-монцонитовых плутонов, синплутонических базитовых интрузий, минглинг-даек и мафических включений в гранитоидах, началось не ранее 305-300 млн лет назад и, по-видимому, достигло максимума около 290 млн лет назад [Tsygankov et al., 2016]. Это согласуется и с массовым формированием гранитоидов смешанного мантийно-корового типа [Tsygankov et al., 2017]. К этому же времени приурочено и становление Брянского и Хоринского массивов $A F S$-сиенитов и $P A$ гранитов, которые в пространстве и времени ассоциируют с бимодальной трахибазальт-трахит-трахириолитовой серией субпараллельных даек - индикаторов тектонического растяжения.

Из этих соотношений следует, что тектоническое сжатие ранней стадии позднепалеозойского гранитоидного магматизма в Забайкалье на рубеже $\approx 300$ млн лет сменилось растяжением, носившим в то время локальный, рассеянный характер. Тем не менее это растяжение, о кинематике которого у нас пока нет данных, сделало кору более проницаемой 
A.A. Tsygankov et al.: Correlation between the mantle and heterochronous crustal materials...

для мантийных магм, что нашло отражение в изменении характера магматизма, в том числе, в массовом формировании А-гранитов.

В мезозое Южное и Центральное Забайкалье представляло собой подвижную зону между двумя разнонаправленно вращающимися крупными литосферными структурами - Сибирью и китайской группой континентальных блоков [Metelkin et al., 2004; 2012]. Сдвиговые деформации в пределах этого пояса привели к широкомасштабному рифтогенезу [Gordienko, Kuzmin, 1999], что сделало литосферу легкопроницаемой для мантийных магм. Последние уже не «задерживались» на нижне- и среднекоровом уровне, а достигали поверхности, формируя вулканическое выполнение мезозойских грабенов. Без дополнительного тепла базитовых интрузий масштабы коровой магмогенерации быстро сокращались, вплоть до ее полного прекращения около 120 млн лет назад.

Таким образом, есть основания полагать, что изотопный состав гранитоидов Забайкалья А-типа обусловлен, с одной стороны, проницаемостью коры для мантийных магм, а с другой - вещественной гетерогенностью собственно коровых источников магм, варьирующихся от раннедокембрийских кристаллических блоков до «молодых» террейнов островодужного типа.

\section{6. ЗАКЛЮЧЕНИЕ}

В результате проведенных исследований установлен U-Pb изотопный возраст щелочных гранитов и гранит-порфиров Кручининского массива,

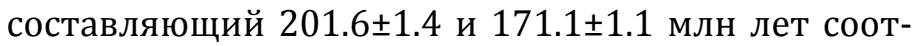
ветственно.

Петрогеохимические данные, полученные по нескольким гранитоидным массивам А-типа, сформировавшимся в разное время в блоках коры «разной степени зрелости», не обнаруживают значимых петро-геохимических различий. Вместе с тем изотопный состав пород (Sm-Nd) варьируется очень широко. Представляется, что ответственность за это несут два основных фактора: а) проницаемость ко- ры для мантийных магм, определяющаяся геодинамической обстановкой, и б) разные пропорции мантийной и коровой составляющих в источнике магм, что в первом приближении может характеризовать «степень зрелости протолита», например докембрийский кристаллический фундамент и раннепалеозойские островодужные террейны.

Длительное формирование А-гранитов в Забайкалье, с конца карбона по ранний мел включительно, вероятно, связано с тем, что южное складчатое обрамление Сибирского кратона (Забайкалье, Северная Монголия) в течение всего этого времени находилось в области горячего поля мантии, испытывая вращательное движение. Геодинамическая обстановка при этом эволюционировала от рассеянного постколлизионного растяжения, до типичного внутриконтинентального рифтогенеза, что, с одной стороны, сопровождалось возрастанием степени взаимодействия мантийных и коровых магм при формировании А-гранитов, а с другой - вело к сокращению салической магмогенерации.

\section{7. БЛАГОДАРНОСТИ}

Авторы выражают благодарность Т.Б. Баяновой (ФИЦ КНЦ РАН, г. Апатиты) за проведение $\mathrm{Sm}-\mathrm{Nd}$ изотопных исследований, О.В. Зарубиной (ЦКП изотопно-геохимических исследований, ИГХ СО PAH, г. Иркутск) за ICP-MS определение микроэлементного состава пород, В.С. Антипину за конструктивные замечания, позволившие улучшить рукопись. $\mathrm{U}-\mathrm{Pb}$ изотопно-геохронологические исследования, определения химического и изотопного (O) состава минералов выполнены в ЦКП «Аналитический центр минералого-геохимических и изотопных исследований» ГИН СО РАН, г. Улан-Удэ. Работа выполнена в рамках программы фундаментальных исследований ГИН СО РАН (базовый проект IX.129.1.2., № гос. рег. ААAА-А16116122110027-2), при поддержке проекта II.1.39. Комплексной программы фундаментальных научных исследований СО РАН и гранта РФФИ № 17-0500275.

\section{8. ЛИТЕРАTУРA / REFERENCES}

Barbarin B., 1999. A review of the relationships between granitoid types, their origins and their geodynamic environments. Lithos 46 (3), 605-626. https://doi.org/10.1016/S0024-4937(98)00085-1.

Bulgatov A.N., Gordienko I.V., 1999. Terrains of the Baikal mountain range and the location of gold deposits. Geology of Ore Deposits 41 (3), 204-213.

Chen G.N., Grapes R., 2007. Granite Genesis: In Situ Melting and Crustal Evolution. Springer, Dordrecht, 278 p. https://doi.org/10.1007/978-1-4020-5891-2.

Collins W.J., Beams S.D., White A.J.R., Chappell B.W., 1982. Nature and origin of A-type granites with particular reference to southeastern Australia. Contributions to Mineralogy and Petrology 80 (2), 189-200. https://doi.org/10.1007/ BF00374895. 
Creaser R.A., Price R.C., Wormald R.J., 1991. A-type granites revisited: assessment of a residual-source model. Geology 19 (2), 163-166. https://doi.org/10.1130/0091-7613(1991)019<0163:ATGRAO>2.3.C0;2.

Eby G.N., 1990. The A-type granitoids: a review of their occurrence and chemical characteristics and speculations on their petrogenesis. Lithos 26 (1-2), 115-134. https://doi.org/10.1016/0024-4937(90)90043-Z

Eby G.N., 1992. Chemical subdivision of the A-type granitoids: petrogenetic and tectonic implications. Geology 20 (7), 641-644. https://doi.org/10.1130/0091-7613(1992)020<0641:CSOTAT>2.3.C0;2.

Frost B.R., Barnes C.G., Collins W.J., Arculus R.J., Ellis D.J., Frost C.D., 2001. A geochemical classification for granitic rocks. Journal of Petrology 42 (11), 2033-2048. https://doi.org/10.1093/petrology/42.11.2033.

Frost C.D., Frost B.R., 2011. On ferroan (A-type) granitoids: their compositional variability and modes of origin. Journal of Petrology 52 (1), 39-53. https://doi.org/10.1093/petrology/egq070.

Gordienko I.V., Kuzmin M.I., 1999. Geodynamics and metallogeny of the Mongolo-Transbaikalian region. Geologiya $i$ Geofizika (Russian Geology and Geophysics) 40 (11), 1545-1562.

Grebennikov A.V., 2014. A-type granites and related rocks: Petrogenesis and classification. Russian Geology and Geophysics 55 (9), 1074-1086. https://doi.org/10.1016/j.rgg.2014.08.003.

Jahn B.M., Litvinovsky B.A., Zanvilevich A.N., Reichow M., 2009. Peralkaline granitoid magmatism in the MongolianTransbaikalian Belt: evolution, petrogenesis and tectonic significance. Lithos 113 (3-4), 521-539. https://doi.org/ 10.1016/j.lithos.2009.06.015.

Khromova E.A., 2008. Material composition and isotope age of the Upper Paleozoic granitoids of the Dzhida Paleozoides Zone (on the example of the Shabartay massif). In: Granites and Earth evolution: geodynamic position, petrogenesis and ore content of granitoid batholiths. Proceedings of the $1^{\text {st }}$ International geological conference. BSC SB RAS Publishing House, Ulan-Ude, p. 399-400 (in Russian) [Хромова E.A. Вещественный состав и изотопный возраст верхнепалеозойских гранитоидов Джидинской зоны палеозоид (на примере Шабартайского массива) // Гранитоиды и эволюция Земли: геодинамическая позиция, петрогенезис и рудоносность гранитоидных батолитов: Материалы I международной геологической конференции. Улан-Удэ: Изд-во БНЦ СО PAH, 2008. C. 399-400].

Khubanov V.B., Buyantuev M.D., Tsygankov A.A., 2016. U-Pb dating of zircons from $\mathrm{PZ}_{3}-\mathrm{MZ}$ igneous complexes of Transbaikalia by sector-field mass spectrometry with laser sampling: technique and comparison with SHRIMP. Russian Geology and Geophysics 57 (1), 190-205. https://doi.org/10.1016/j.rgg.2016.01.013.

Khubanov V.B., Vrublevskaya T.T., Tsyrenov B.T., Tsygankov A.A., 2015. Formation of the trachybasalt-trachyte bimodal series of the Malo-Khamardaban volcanotectonic complex, southwestern Transbaikalia: Role of fractional crystallization and magma mixing. Petrology 23 (5), 451-479. https://doi.org/10.1134/S0869591115040037.

Kruk N.N., Rudnev S.N., Vladimirov A.G., Shokalsky S.P., Kovach V.P., Serov P.A., Volkova N.I., 2011. Early-Middle Paleozoic granitoids in Gorny Altai, Russia: Implications for continental crust history and magma sources. Journal of Asian Earth Sciences 42 (5), 928-948. https://doi.org/10.1016/j.jseaes.2010.12.008.

Leake B.E., Woolley A.R., Arps C.E.S., Birch W.D., Gilbert M.C., Grice J.D., Hawthorne F.C., Kato A., Kisch H.J., Krivovichev V.G., Linthout K., Laird J., Mandarino J.A., Maresch W.V., Nickel E.H., Rock N.M.S., Schumacher J.C., Smith D.C., Stephenson N.C.N., Ungaretti L., Whittaker E.J.W., Youzhi G., 1997. Nomenclature of amphiboles; report of the subcommittee on amphiboles of the International Mineralogical Association, Commission on New Minerals and Mineral Names. The Canadian Mineralogist 35 (1), 219-246.

Liégeois J.P., Black R., 1987. Alkaline magmatism subsequent to collision in the Pan-African belt of the Adrar des Iforas (Mali). In: J.G. Fitton, B.G.J. Upton (Eds.), Alkaline igneous rocks. Geological Society, London, Special Publications, vol. 30, p. 381-401. https://doi.org/10.1144/GSL.SP.1987.030.01.18.

Litvinovsky B.A., Jahn B.M., Zanvilevich A.N., Saunders A., Poulain S., Kuzmin D.V., Reichow M.K., Titov A.V., 2002. Petrogenesis of syenite-granite suites from the Bryansky Complex (Transbaikalia, Russia): implications for the origin of A-type granitoid magmas. Chemical Geology 189 (1-2), 105-133. https://doi.org/10.1016/S0009-2541(02) 00142-0.

Litvinovsky B.A., Tsygankov A.A., Jahn B.M., Katzir Y., Be'eri-Shlevin Y., 2011. Origin and evolution of overlapping calcalkaline and alkaline magmas: The Late Palaeozoic post-collisional igneous province of Transbaikalia (Russia). Lithos 125 (3-4), 845-874. https://doi.org/10.1016/j.lithos.2011.04.007.

Loiselle M.C., Wones D.R., 1979. Characteristics and origin of anorogenic granites. In: Abstracts of papers to be presented at the annual meetings of the Geological Society of America and Associated Societies, Vol. 11, No. 7. San Diego, California, p. 468.

Metelkin D.V., Gordienko I.V., Zhao X.X., 2004. Paleomagnetism of Early Cretaceous volcanic rocks from Transbaikalia: argument for Mesozoic strike-slip motions in Central Asian structure. Geologiya i Geofizika (Russian Geology and Geophysics) 45 (12), 1349-1363.

Metelkin D.V., Vernikovsky V.A., Kazansky A.Y., 2012. Tectonic evolution of the Siberian paleocontinent from the Neoproterozoic to the Late Mesozoic: paleomagnetic record and reconstructions. Russian Geology and Geophysics 53 (7), 675-688. https://doi.org/10.1016/j.rgg.2012.05.006.

Patiño Douce A.E., 1997. Generation of metaluminous A-type granites by low-pressure melting of calc-alkaline granitoids. Geology 25 (8), 743-746. https://doi.org/10.1130/0091-7613(1997)025<0743:GOMATG>2.3.C0;2. 
Petrographic Code of Russia. Magmatic, Metamorphic, Metasomatic, Impact Rock-Assemblages, 2009. VSEGEI Press, Saint Petersburg, 200 p. (in Russian) [Петрографический кодекс России. Магматические, метаморфические, метасоматические, импактные образования. СПб.: Изд-во ВСЕГЕИ, 2009. 200 с.].

Reichow M.K., Litvinovsky B.A., Parrish R.R., Saunders A.D., 2010. Multi-stage emplacement of alkaline and peralkaline syenite-granite suites in the Mongolian-Transbaikalian belt, Russia: Evidence from U-Pb geochronology and whole rock geochemistry. Chemical Geology 273 (1-2), 120-135. https://doi.org/10.1016/j.chemgeo.2010.02.017.

Reznitsky L.Z., Barash I.G., Kovach V.P., Belichenko V.G., Sal'nikova E.B., Kotov A.B., 2005. Paleozoic intrusive magmatism of the Dzhida terrane - new geochronological and Nd isotope data. In: Geodynamic evolution of the lithosphere of the Central Asian mobile belt (from ocean to continent). Issue 3, Vol. 2. IEC SB RAS, Irkutsk, p. 77-80 (in Russian) [Резницкий Л.З., Бараш И.Г., Ковач В.П., Беличенко В.Г., Сальникова Е.Б., Котов А.Б. Палеозойский интрузивный магматизм Джидинского террейна - новые геохронологические и $\mathrm{Nd}$ изотопные данные // Геодинамическая эволюция литосферы Центрально-Азиатского подвижного пояса (от океана к континенту). Вып. 3. Иркутск: ИЗК СО РАН, 2005. Т. 2. С. 77-80].

Rudnick R.L., Gao S., 2003. Composition of the continental crust. In: H.D. Holland, K.K. Turekian (Eds.), Treatise on geochemistry, Vol. 3. Elsevier, Oxford, p. 1-64. https://doi.org/10.1016/B0-08-043751-6/03016-4.

Ruzhentsev S.V., Minina O.R., Nekrasov G.E., Aristov V.A., Golionko B.G., Doronina N.A., Lykhin D.A., 2012. The Baikal-Vitim fold system: structure and geodynamic evolution. Geotectonics 46 (2), 87-110. https://doi.org/10.1134/S0016 852112020033.

Sun S.-S., McDonough W.F., 1989. Chemical and isotopic systematics of oceanic basalts: implications for mantle composition and processes. In: A.D. Saunders, M.J. Norry (Eds.), Magmatism in the ocean basins. Geological Society, London, Special Publications, vol. 42, p. 313-345. https://doi.org/10.1144/GSL.SP.1989.042.01.19.

Sylvester P.J., 1989. Post-collisional alkaline granites. The Journal of Geology 97 (3), 261-280. https://doi.org/ $10.1086 / 629302$.

Tsygankov A.A., 2014. Late Paleozoic granitoids in Western Transbaikalia: sequence of formation, sources of magmas, and geodynamics. Russian Geology and Geophysics 55 (2), 153-176. https://doi.org/10.1016/j.rgg.2014.01.004.

Tsygankov A.A., Burmakina G.N., Khubanov V.B., Buyantuev M.D., 2017. Geodynamics of Late Paleozoic batholithforming processes in Western Transbaikalia. Petrology 25 (4), 396-418. https://doi.org/10.1134/S086959111 7030043

Tsygankov A.A., Dugdanova E.E., Burmakina G.N., Udoratina O.V., Khubanov V.B., 2015. Alkaline granitoid magmatism in Western Transbaikalia: geochronology, rock composition, geodynamics. In: Geodynamic evolution of the lithosphere of the Central Asian mobile belt (from ocean to continent). Issue 13. IEC SB RAS, Irkutsk, p. 249-251 (in Russian) [Цыганков А.А., Дугданова Е.Е., Бурмакина Г.Н., Удоратина О.В., Хубанов В.Б. Щелочно-гранитоидный магматизм Западного Забайкалья: геохронология, состав пород, геодинамика // Геодинамическая эволюция литосферы Центрально-Азиатского подвижного пояса (от океана к континенту): Вып. 13. Иркутск: ИЗК СО РАН, 2015. С. 249-251].

Tsygankov A.A., Khubanov V.B., Travin A.V., Lepekhina E.N., Burmakina G.N., Antsiferova T.N., Udoratina O.V., 2016. Late Paleozoic gabbroids of Western Transbaikalia: U-Pb and Ar-Ar isotopic ages, composition, and petrogenesis. Russian Geology and Geophysics 57 (5), 790-808. https://doi.org/10.1016/j.rgg.2015.09.019.

Tsygankov A.A., Litvinovsky B.A., Jhan B.M., Reichow M.K., Liu D.Y., Larionov A.N., Presnykov S.L., Lepekhina Ye.N., Sergeev S.A., 2010. Sequence of magmatic events in the Late Paleozoic of Transbaikalia, Russia (U-Pb isotope data). Russian Geology and Geophysics 51 (9), 972-994. https://doi.org/10.1016/j.rgg.2010.08.007.

Tsygankov A.A., Matukov D.I., Berezhnaya N.G., Larionov A.N., Posokhov V.F., Tsyrenov B.Ts., Khromov A.A., Sergeev S.A., 2007. Late Paleozoic granitoids of Western Transbaikalia: magma sources and stages of formation. Russian Geology and Geophysics 48 (1), 120-140. https://doi.org/10.1016/j.rgg.2006.12.011.

Turner S.P., Foden J.D., Morrison R.S., 1992. Derivation of some A-type magmas by fractionation of basaltic magma: an exemple from the Pathway ridge, South Australia. Lithos 28 (2), 151-179 https://doi.org/10.1016/00244937(92)90029-X.

Vorontsov A.A., Yarmolyuk V.V., 2007. The evolution of volcanism in the Tugnui-Khilok sector of the Western Transbaikalia rift area in the Late Mesozoic and Cenozoic. Journal of Volcanology and Seismology 1 (4), 213-236. https://doi.org/10.1134/S074204630704001X.

Whalen J.B., Currie K.L., Chappell B.W., 1987. A-type granites: geochemical characteristics, discrimination and petrogenesis. Contributions to Mineralogy and Petrology 95 (4), 407-419. https://doi.org/10.1007/BF00402202.

White A.J.R., 1979. Sources of granite magmas. In: Abstracts of papers to be presented at the annual meetings of the Geological Society of America and Associated Societies, Vol. 11, No. 7. San Diego, California, p. 539.

Wu F.Y., Sun D.Y., Li H.M., Jahn B.M., Wilde S.A., 2002. A-type granites in Northeaster China: age and geochemical constraints on their petrogenesis. Chemical Geology 187 (1-2), 143-173 https://doi.org/10.1016/S0009-2541(02) 00018-9.

Yarmolyuk V.V., Budnikov S.V., Kovalenko V.I., Antipin V.S., Goreglyad A.V., Sal'nikova E.B., Kotov A.B., Kozakov I.A., Kovach V.P., Yakovleva Z.S., Berezhnaya N.G., 1997. Geochronology and geodynamic setting of the Angara-Vitim batholith. Petrology 5 (5), 401-414. 
Yarmolyuk V.V., Ivanov V.G., Kovalenko V.I., 1998. Sources of intraplate magmatism of Western Transbaikalia in the Late Mesozoic - Cenozoic: trace-element and isotope data. Petrology 6 (2), 101-123.

Yarmolyuk V.V., Kuzmin M.I., Ernst R.E., 2014. Intraplate geodynamics and magmatism in the evolution of Central Asian orogenic belt. Journal of Asian Earth Sciences 93, 158-179. https://doi.org/10.1016/j.jseaes.2014.07.004.

Yarmolyuk V.V., Kuzmin M.I., Kozlovsky A.M., 2013. Late Paleozoic - Early Mesozoic within-plate magmatism in North Asia: traps, rifts, giant batholiths, and the geodynamics of their origin. Petrology 21 (2), 101-126. https://doi.org/ 10.1134/S0869591113010062.

Zanvilevich A.N., Litvinovsky B.A., Wickham S.M., Bea F., 1995. Genesis of alkaline and peralkaline syenite-granite series: the Kharitonovo pluton (Transbaikalia, Russia). The Journal of Geology 103 (2), 127-145. https://doi.org/ $10.1086 / 629732$.

Zonenshain L.P., Kuzmin M.I., Natapov L.M., 1990. Plate Tectonics of the USSR Territory. Vol. 1. Nedra, Moscow, 326 p. (in Russian) [Зоненшайн Л.П., Кузьмин М.И., Натапов Л.М. Тектоника литосферных плит территории СССР. М.: Недра, 1990. Т. 1. 326 с.].

\section{CВЕДЕНИЯ ОБ АВTOPAX | INFORMATION ABOUT AUTHORS}

Андрей Александрович Цыганков

докт. геол.-мин. наук, директор

Геологический институт СО РАН

670047, Улан-Удэ, ул. Сахьяновой, 6а, Россия

Бурятский государственный университет 670000, Улан-Удэ, ул. Смолина, 24a, Россия

凶e-mail: tsygan@ginst.ru

\section{Валентин Борисович Хубанов}

канд. геол.-мин. наук, с.н.с.

Геологический институт СО РАН

670047, Улан-Удэ, ул. Сахьяновой, 6а, Россия

Бурятский государственный университет

670000, Улан-Удэ, ул. Смолина, 24a, Россия

e-mail: khubanov@mail.ru

\section{Галина Николаевна Бурмакина}

канд. геол.-мин. наук, н.с.

Геологический институт СО РАН

670047, Улан-Удэ, ул. Сахьяновой, 6а, Россия

e-mail: gerka_85@mail.ru

Алексей Леонидович Елбаев

канд. геол.-мин. наук, н.с.

Геологический институт СО РАН

670047, Улан-Удэ, ул. Сахьяновой, 6а, Россия

e-mail: elbaev@ginst.ru

\footnotetext{
Валерий Васильевич Бурдуковский аспирант

Геологический институт СО РАН

670047, Улан-Удэ, ул. Сахьяновой, 6а, Россия

e-mail: burdukovskii_valera@mail.ru
}

Andrei A. Tsygankov

Doctor of Geology and Mineralogy, Director

Geological Institute, Siberian Branch of RAS

6a Sakhyanova street, Ulan-Ude 670047, Russia

Buryat State University

24a Smolin street, Ulan-Ude 670000, Russia

\section{Valentin B. Khubanov}

Candidate of Geology and Mineralogy, Senior Researcher

Geological Institute, Siberian Branch of RAS

6a Sakhyanova street, Ulan-Ude 670047, Russia

Buryat State University

24a Smolin street, Ulan-Ude 670000, Russia

\section{Galina N. Burmakina}

Candidate of Geology and Mineralogy, Researcher

Geological Institute, Siberian Branch of RAS

6a Sakhyanova street, Ulan-Ude 670047, Russia

\section{Aleksei L. Elbaev}

Candidate of Geology and Mineralogy, Researcher

Geological Institute, Siberian Branch of RAS

6a Sakhyanova street, Ulan-Ude 670047, Russia

\section{Valeriy V. Burdukovsky}

Post-Graduate Student

Geological Institute, Siberian Branch of RAS

6a Sakhyanova street, Ulan-Ude 670047, Russia 